\title{
Localized scleroderma - classification and tools used for the evaluation of tissue damage and disease activity/severity
}

\author{
Twardzina ograniczona - klasyfikacja i narzędzia stosowane do oceny uszkodzenia \\ tkanek, aktywności lub nasilenia choroby
}

Katarzyna Wolska-Gawron, Dorota Krasowska

Department of Dermatology, Venereology and Paediatric Dermatology, Medical University of Lublin, Poland

Klinika Dermatologii, Wenerologii i Dermatologii Dziecięcej Uniwersytetu Medycznego w Lublinie, Polska

Dermatol Rev/Przegl Dermatol 2017, 104, 269-289

DOI: https://doi.org/l0.5। |4/dr.2017.68775

\author{
CORRESPONDING AUTHOR/ \\ ADRES DO KORESPONDECJI: \\ lek. Katarzyna Wolska-Gawron \\ Klinika Dermatologii, Wenerologii \\ i Dermatologii Dziecięcej \\ Uniwersytet Medyczny w Lublinie \\ ul. Radziwiłłowska 13 \\ 20-080 Lublin, Polska \\ faks: +48 601334711 \\ e-mail: wolskak@poczta.onet.pl
}

\begin{abstract}
Localized scleroderma is a rare autoimmune disorder affecting the dermis, subcutaneous tissue and deeper structures. The course of localized scleroderma includes three stages: early inflammation, progressive sclerosis and atrophy. The active stage of the disease is characterized by erythema ('lilac ring'), skin induration, and appearance of new or expansion of pre-existing skin lesions during the preceding month. The most recent localized scleroderma classification recognizes five types of the disease: localized, generalized, linear, deep and mixed. Various methods have been proposed for the evaluation of disease activity or severity and tissue damage, including ultrasonography, thermography, durometry, computed tomography and magnetic resonance imaging. However, all of them have their limitations, as they only make it possible to assess one component of the disease: activity or severity or tissue damage. The LS Cutaneous Assessment Tool (LoSCAT) questionnaire is a promising method of patient evaluation because of its availability, repeatability of results and sensitivity to changes resulting from treatment.
\end{abstract}

\section{STRESZCZENIE}

Twardzina ograniczona jest rzadką chorobą autoimmunologiczną, która przebiega z zajęciem skóry, tkanki podskórnej i tkanek głębiej położonych. Choroba klinicznie ma trzy fazy: wczesną zapalną, postępującego stwardnienia i zanikową (atroficzną). Wykładnikami aktywnego procesu chorobowego są: rumień (lilac ring), stwardnienie skóry, pojawianie się nowych wykwitów skórnych lub powiększenie wcześniej istniejących zmian w ciągu ostatniego miesiąca. Najnowsza klasyfikacja wyróżnia pięć typów twardziny ograniczonej: ograniczona, uogólniona, linijna, głęboka i mieszana. Zaproponowano wiele metod oceny aktywności lub nasilenia choroby oraz uszkodzenia tkanek, takich jak ultrasonografia, termografia, durometria, tomografia komputerowa czy rezonans magnetyczny. Ograniczenia powyższych badań wynikają z możliwości oceny tylko jednego wykładnika - aktywności lub nasilenia choroby albo uszkodzenia tkanek. Przedstawiona metoda ewaluacji pacjentów oparta na zastosowaniu kwestionariusza do oceny aktywności i nasilenia choroby (LoSCAT) jest 
godna uwagi ze względu na dostępność narzędzia, powtarzalność wyników, a także czułość formularza na zmiany wynikające z zastosowanego leczenia.

Key words: classification, localized scleroderma, damage, severity, LoSCAT.

Słowa kluczowe: klasyfikacja, twardzina ograniczona, uszkodzenie, aktywność, LoSCAT.

\section{INTRODUCTION}

Localized scleroderma (LoSc, morphea) is a chronic disease of connective tissue which is characterized by circumscribed cutaneous sclerosis, often with involvement of underlying tissues: fasciae, muscles and bones. The disease may also cause disorders of the musculoskeletal and nervous systems as well as ophthalmological manifestations which occur most commonly in patients with linear localized scleroderma. The incidence of LoSc is $0.4-2.7$ cases/100,000 persons/year, with a peak age of onset at $20-40$ years. It is more common in the Caucasian population, and in women (female-to-male ratio $4: 2$ ) [1-3]. Children under 10 years of age represent approximately $15 \%$ of the patient population [4]. The aetiopathogenesis of LoSc has not been clearly understood, but it is believed that it involves primarily genetic and environmental factors together with immune and vascular disorders. The clinical course of LoSc includes three stages: early inflammation (active stage persisting for an average of 3-4 years), progressive sclerosis and atrophy (Fig. 1) $[5,6]$. In the majority of cases LoSc does not progress to systemic sclerosis, however there have been reports on the development of LoSc in the course of systemic sclerosis with limited scleroderma [2]. Approximately $25 \%$ of patients show regression of cutaneous lesions after various periods - in cases of plaque morphea after about 2.5 years, and in cases of linear, deep and generalized LoSc after about 5.5 years [2,7]. A retrospective analysis conducted in a group of 344 patients demonstrated disease recurrence in $27 \%$ of patients with paediatric-onset and in $17 \%$ of patients with adult-onset LoSc [7]. The association between disease recurrence and LoSc subtype was statistically significant for linear LoSc of the limbs subtype, which shows that patients with this clinical form of LoSc require prolonged aggressive treatment [7].

\section{WSTĘP}

Twardzina ograniczona (LoSc, morphea) jest przewlekłą chorobą tkanki łącznej, która charakteryzuje się ograniczonym stwardnieniem skóry, a także często zajęciem tkanek głębiej położonych - powięzi, mięśni, kości. W przebiegu choroby mogą wystąpić zaburzenia układu mięśniowo-szkieletowego, nerwowego, a także narządu wzroku, które dotyczą najczęściej pacjentów z linijną odmianą twardziny. Szacuje się, że zapadalność na LoSc wynosi 0,4-2,7 przypadku/ 100000 osób/rok, a szczyt zachorowań przypada między 20. a 40. rokiem życia. Choroba częściej wystepuje u osób rasy kaukaskiej i płci żeńskiej (kobiety : mężczyźni - 4 : 2) [1-3]. Około 15\% chorych stanowią dzieci do 10. roku życia [4]. Etiopatogeneza LoSc nie została w pełni poznana, ale przypuszcza się, że decydujące znaczenie w rozwoju schorzenia mają czynniki genetyczne i środowiskowe, a także zaburzenia immunologiczne i naczyniowe. Choroba klinicznie obejmuje trzy fazy: wczesną zapalną (aktywną, utrzymującą się średnio przez 3-4 lata), postępującego stwardnienia i zanikową (atroficzną) (ryc. 1) $[5,6]$. Twardzina ograniczona przeważnie nie ulega progresji do układowej postaci twardziny, chociaż są doniesienia o pojawianiu się LoSc w przebiegu twardziny układowej z ograniczonymi stwardnieniami skóry [2]. U ok. 25\% pacjentów można obserwować remisję zmian skórnych po różnym czasie trwania w przypadku twardziny plackowatej po ok. 2,5 roku, natomiast w przypadku odmiany linijnej, głębokiej i uogólnionej czas ten jest wydłużony do ok. 5,5 roku $[2,7]$. W badaniu retrospektywnym przeprowadzonym w grupie 344 chorych wykazano nawroty u $27 \%$ pacjentów z LoSc o początku w okresie dziecięcym oraz u $17 \%$ chorych z LoSc o początku w wieku dorosłym [7]. Związek pomiędzy nawrotem choroby a podtypem LoSc był istotny statystycznie w przypadku LoSc linijnej kończyn, co świadczy o konieczności agresywnej, przedłużonej terapii powyższej odmiany klinicznej LoSc [7]. 

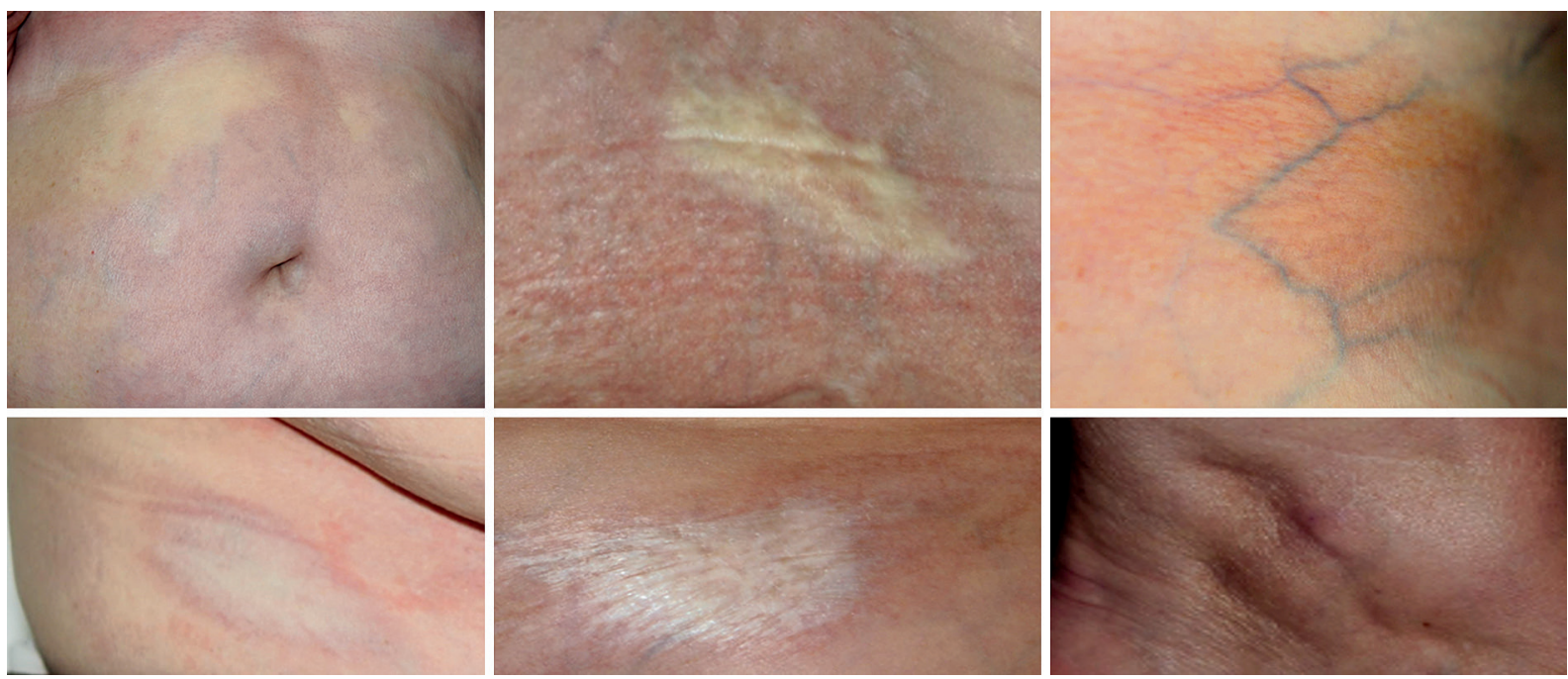

Figure I. Clinical stages of morphea - inflammation, sclerosis, atrophy

Rycina I. Kliniczne fazy twardziny ograniczonej-zapalenie, stwardnienie, zanik

Table I. Classification of LoSc (morphea) according to Peterson et al., 1995 (The Mayo Clinic Classification) [7] Tabela I. Klasyfikacja LoSc wg Petersona i wsp. z 1995 r. (Mayo Clinic Classification) [7]

\begin{tabular}{|c|c|}
\hline Morphea type/Typ twardziny & Morphea subtype/Podtyp twardziny \\
\hline \multirow[t]{5}{*}{ plaque morphea/twardzina plackowata } & plaque morphea/plackowata \\
\hline & guttate morphea/grudkowa \\
\hline & $\begin{array}{l}\text { atrophoderma of Pasini and Pierini/ograniczona pierwotnie } \\
\text { zanikowa }\end{array}$ \\
\hline & keloid/nodular morphea/guzkowa lub keloidowa \\
\hline & lichen sclerosus et atrophicus/liszaj twardzinowy \\
\hline generalized morphea/twardzina uogólniona & - \\
\hline bullous morphea/twardzina pęcherzowa & - \\
\hline \multirow[t]{3}{*}{ linear morphea/twardzina linijna } & linear morphea/inijna \\
\hline & morphea en coup de sabre/linijna typu cięcia szablą \\
\hline & progressive facial hemiatrophy/postępujący zanik połowiczy twarzy \\
\hline \multirow[t]{4}{*}{ deep morphea/twardzina głęboka } & morphea profunda/skórna głęboka \\
\hline & subcutaneous morphea/podskórna \\
\hline & eosinophilic fasciitis/eozynofilowe zapalenie powięzi \\
\hline & pansclerotic morphea/zniekształcająca głęboka \\
\hline
\end{tabular}

\section{CLASSIFICATION OF LOCALIZED SCLERODERMA}

Localized scleroderma is characterized by a spectrum of clinical forms differing in the morphology of lesions and the extent and depth of sclerosis. The first classification of LoSc was proposed in 1995 by Peterson et al. (Mayo Clinic Classification) [8], who distinguished five main forms of the disease: plaque morphea, generalized morphea, bullous morphea, linear morphea and deep morphea (Table 1) [8]. The classification also included lichen sclerosus, eosinophilic fasciitis and atrophoderma of Pasini and Pierini [9, 10]. A controversial aspect of the classification system was the fact that it excluded mixed scleroderma types which occur in almost $15 \%$ of patients [9]. In

\section{KLASYFIKACJA TWARDZINY OGRANICZONEJ}

Twardzina ograniczona obejmuje spektrum postaci klinicznych, które różnią się morfologią zmian oraz rozległością i głębokością stwardnień. Pierwsza klasyfikacja LoSc została przedstawiona w 1995 r. przez Petersona i wsp. (Mayo Clinic Classification) [8], którzy wyróżnili pięć głównych odmian twardziny - plaque morphea, generalized morphea, bullous morphea, linear morphea, deep morphea (tab. 1) [8]. Wspomniana klasyfikacja obejmowała także: liszaj twardzinowy, eozynofilowe zapalenie powięzi oraz twardzinę ograniczoną pierwotnie zanikową $[9,10]$. Dyskusyjne w tych klasyfikacjach było nieuwzględnienie postaci mieszanych twardziny, które występują u blisko 
Table 2. Classification of LoSc according to the Paediatric Rheumatology European Society, 2004 (Consensus Conference, Padua, Italy) [I I] Tabela 2. Klasyfikacja LoSc wg Europejskiego Towarzystwa Reumatologów Dziecięcych z 2004 r. (Padwa, Włochy) [1 I]

\begin{tabular}{|c|c|c|c|}
\hline Туре/Тур & \multicolumn{2}{|c|}{ Subtype/Podtyp } & Description/Opis \\
\hline \multirow[t]{2}{*}{$\begin{array}{l}\text { circumscribed } \\
\text { morphea /ograniczona }\end{array}$} & \multicolumn{2}{|c|}{ superficial/powierzchowna } & $\begin{array}{l}\text { oval areas of induration limited to epidermis and dermis/owalne ogniska } \\
\text { ze stwardnieniem ograniczonym do naskórka i skóry właściwej }\end{array}$ \\
\hline & \multicolumn{2}{|l|}{ deep/głęboka } & $\begin{array}{l}\text { oval deep induration of the skin extending beyond subcutaneous } \\
\text { tissue (sometimes without involvement of the skin)/owalne ogniska ze } \\
\text { stwardnieniem przekraczającym tkankę podskórną (skóra pokrywająca } \\
\text { zmiany może być niezmieniona) }\end{array}$ \\
\hline \multirow[t]{3}{*}{$\begin{array}{l}\text { linear scleroderma/ } \\
\text { linijna }\end{array}$} & \multicolumn{2}{|c|}{$\begin{array}{l}\text { trunk/limbs/zajęcie kończyn } \\
\text { lub tułowia }\end{array}$} & $\begin{array}{l}\text { linear induration involving dermis and subcutaneous tissue (sometimes } \\
\text { also muscle and underlying bone)/linijne stwardnienia obejmujące skórę } \\
\text { i tkankę podskórną (mogą obejmować mięśnie i kości) }\end{array}$ \\
\hline & \multirow[t]{2}{*}{$\begin{array}{l}\text { head/zajęcie } \\
\text { głowy }\end{array}$} & $\begin{array}{l}\text { en coup de sabre/ } \\
\text { typu cięcia szablą }\end{array}$ & $\begin{array}{l}\text { linear induration that affects the face and the scalp (sometimes also } \\
\text { muscle, underlying bone and CNS)/linijne stwardnienia obejmujące skórę } \\
\text { twarzy i głowy (mogą obejmować mięśnie, kości, OUN) }\end{array}$ \\
\hline & & $\begin{array}{l}\text { progressive facial } \\
\text { hemiatrophy/ } \\
\text { postępujący zanik } \\
\text { połowiczy twarzy }\end{array}$ & $\begin{array}{l}\text { atrophy of tissue on one side of the face that may involve dermis, } \\
\text { subcutaneous tissue, muscle and bone/jednostronny zanik skóry, tkanki } \\
\text { podskórnej, mięśni i kości twarzy }\end{array}$ \\
\hline $\begin{array}{l}\text { generalized morphea/ } \\
\text { uogólniona }\end{array}$ & \multicolumn{2}{|l|}{-} & $\begin{array}{l}\geq 4 \text { areas of skin induration, } \geq 3 \mathrm{~cm} \text { in diameter, involving } \geq 2 \text { anatomic } \\
\text { sites (head-neck, all extremities, anterior trunk, posterior trunk)/ } \\
\geq 4 \text { ogniska stwardnienia o średnicy } \geq 3 \mathrm{~cm} \text { występujące } w \geq 2 \text { okolicach } \\
\text { anatomicznych (twarz-szyja, każda z kończyn, przednia powierzchnia } \\
\text { tułowia, tylna powierzchnia tułowia) }\end{array}$ \\
\hline $\begin{array}{l}\text { pansclerotic morphea/ } \\
\text { zniekształcająca } \\
\text { głęboka }\end{array}$ & \multicolumn{2}{|l|}{-} & $\begin{array}{l}\text { circumferential involvement of limb(s) affecting the epidermis, dermis, } \\
\text { subcutaneous tissue, muscle and bone/zajęcie obwodowych odcinków } \\
\text { kończyn, obejmujące naskórek, skórę właściwą, tkankę podskórną, } \\
\text { mięśnie i kości }\end{array}$ \\
\hline $\begin{array}{l}\text { mixed morphea/ } \\
\text { mieszana }\end{array}$ & \multicolumn{2}{|l|}{-} & $\begin{array}{l}\text { combination of } \geq 2 \text { localized scleroderma subtypes/współwystępowanie } \\
\geq 2 \text { podtypów twardziny ograniczonej }\end{array}$ \\
\hline
\end{tabular}

Table 3. Classification of LoSc according to the European Dermatology Forum guideline and Kreuter et al., 2016 [2]

Tabela 3. Klasyfikacja LoSc wg wytycznych European Dermatology Forum oraz Kreutera i wsp. z 2016 r. [2]

\begin{tabular}{|c|c|}
\hline Type of LoSc/Typ LoSc & Subtype/Podtyp \\
\hline \multirow[t]{3}{*}{ limited/ograniczona } & plaque/plackowata \\
\hline & guttate/grudkowa \\
\hline & atrophoderma of Pasini and Pierini (superficial)/ograniczona pierwotnie zanikowa (powierzchowna) \\
\hline \multirow[t]{3}{*}{ generalized*/uogólniona* } & generalized localized/ograniczona uogólniona \\
\hline & disabling pansclerotic morphea/zniekształcająca głęboka \\
\hline & eosinophilic fasciitis/eozynofilowe zapalenie powięzi \\
\hline \multirow[t]{3}{*}{ linear/linijna } & linear (usually affecting the extremities)/linijna kończyn \\
\hline & en coup de sabre/typu cięcia szablą \\
\hline & progressive facial hemiatrophy (Parry-Romberg syndrome)/postępujący zanik połowiczy twarzy \\
\hline deep*/głęboka* & deep/głęboka \\
\hline mixed/mieszana & $\left.\begin{array}{l}\text { linear + plaque/linijna + plackowata } \\
\text { linear }+ \text { generalized/linijna }+ \text { uogólniona }\end{array}\right\}$ most common/najczęstsze \\
\hline
\end{tabular}

*Eosinophilic fasciitis is a special form of LoSc that may be classified as both generalized and deep limited LoSc./*Eozynofilowe zapalenie powięzi jest szczególna formą LoSc, która może być zaliczana zarówno do odmiany uogólnionej, jak i głębokiej twardziny ograniczonej.

2004 the Paediatric Rheumatology European Society proposed a new classification of LoSc in children which is a modified version of Peterson's classification excluding scleroderma-like disorders (Table 2) [11]. Also, the European Dermatology Forum and Kreuter et al. presented a new systematic classification of LoSc which also includes the mixed type of LoSc (Table 3) [2, 12].
15\% chorych [9]. W 2004 r. Europejskie Towarzystwo Reumatologów Dziecięcych przedstawiło propozycję nowej klasyfikacji LoSc u dzieci, która jest modyfikacją podziału Petersona, z wyłączeniem stanów rzekomotwardzinowych (tab. 2) [11]. Europejskie Forum Dermatologiczne oraz Kreuter i wsp. zaproponowali nową systematykę LoSc, w której uwzględniono także postać mieszaną (tab. 3) [2, 12]. 


\section{Limited form of localized scleroderma}

- Plaque morphea - oval/round lesions, $>1 \mathrm{~cm}$ in diameter, occurring in one or two different anatomical locations (usually within the trunk-groin area, lower abdomen, submammary region and extremities) [2]. Plaques initially appear erythematous and are circumscribed by an inflammatory halo, bluish red or violaceous in colour (lilac ring) (Fig. 2 A). Over the course of the disease, lesions become ivory-coloured and increasingly hardened at the centre. While resolving, the induration may leave behind atrophic changes devoid of hair and sweat glands, appear-

\section{Twardzina ograniczona}

- Twardzina plackowata (plaque morphea) - owalne lub okrągłe ogniska o średnicy $>1 \mathrm{~cm}$, które występują w 1 lub 2 odmiennych lokalizacjach (najczęściej tułów - pachwiny, podbrzusze, okolica podpiersiowa; kończyny) [2]. Blaszki mają początkowo barwę rumieniową i są otoczone sinoczerwoną lub fioletową obwódką zapalną (lilac ring) (ryc. 2 A). Z czasem przyjmują barwę kości słoniowej, a w centrum obecne jest stwardnienie, które ustępując, może pozostawiać zmiany atroficzne, pozbawione włosów i gruczołów potowych, hipo- lub hiperpig-
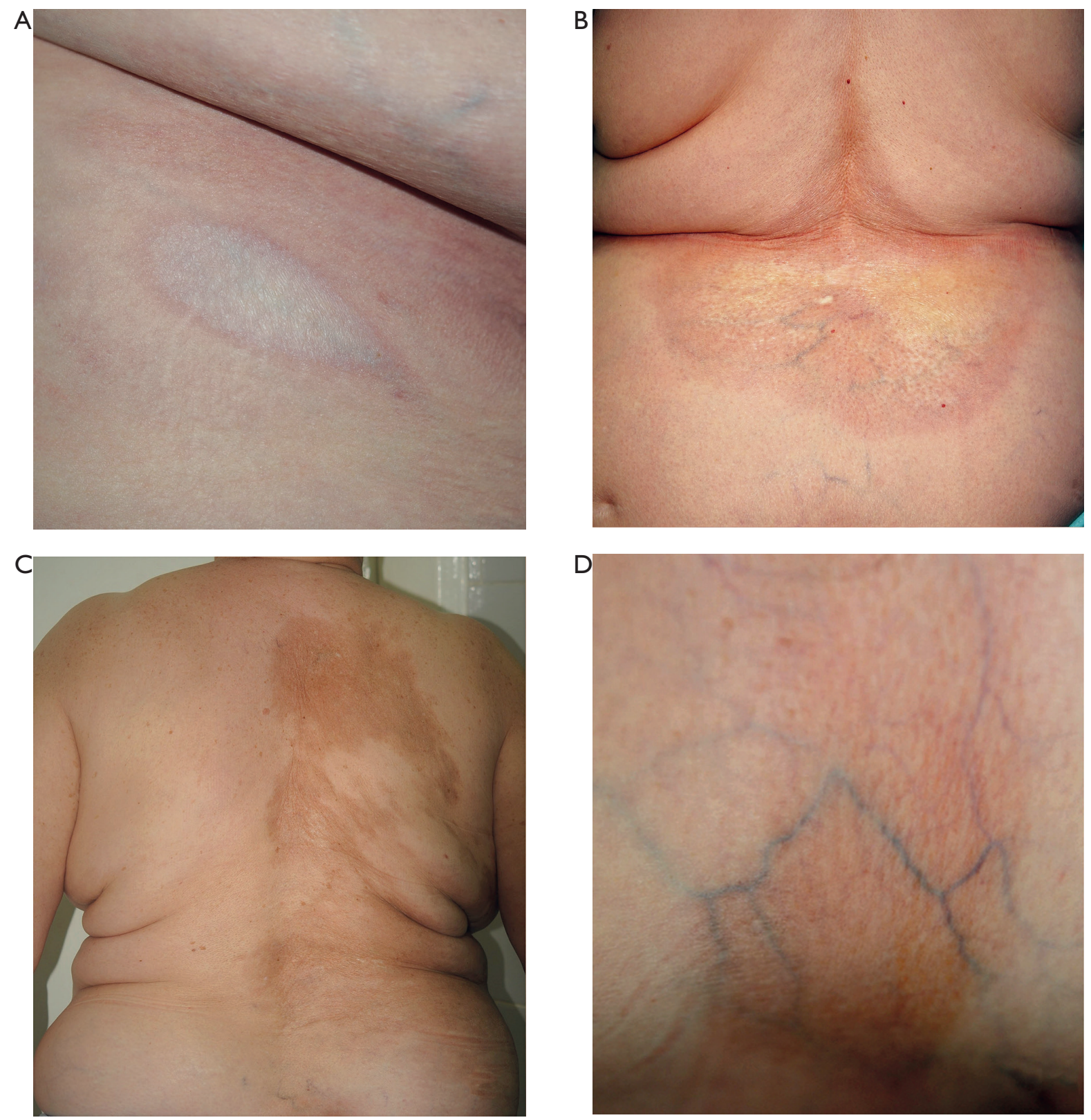

Figure 2. Plaque morphea. A - Erythematous inflammatory halo (lilac ring). B - Morphea lesion with sclerotic ivory-coloured centre, erythema and atrophy. C - Hyperpigmented atrophic patches. D - Atrophic patch

Rycina 2. Twardzina ograniczona plackowata. A - Rumieniowa obwódka zapalna. B - Centralne stwardnienie barmy kości słoniowej, zmiany rumieniowe i zanikowe. C - Hiperpigmentacyjne zmiany zanikowe. D - Ognisko atroficzne 


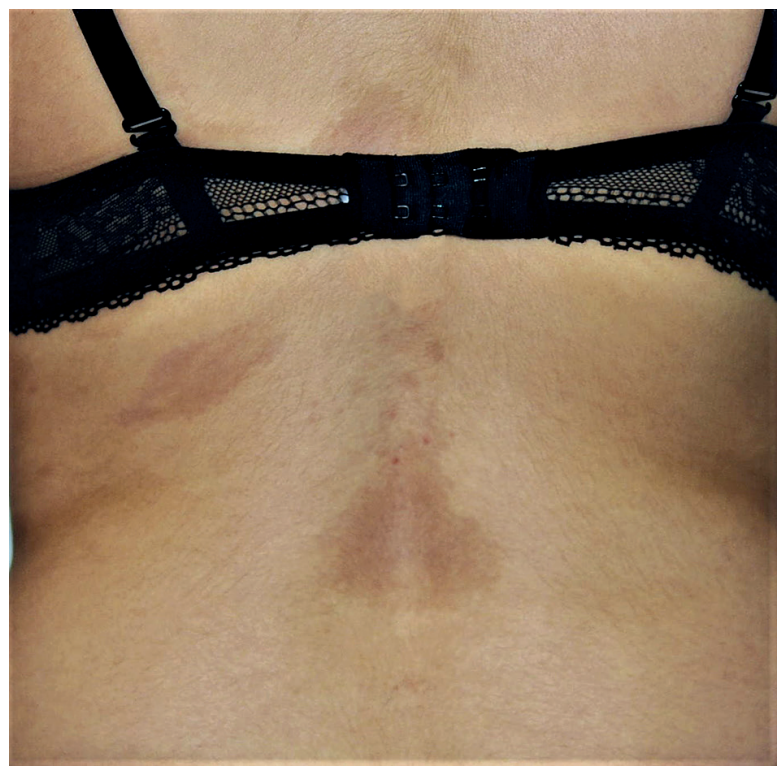

Figure 3. Atrophoderma of Pasini and Pierini

Rycina 3. Twardzina ograniczona pierwotnie zanikowa

ing hypo- or hyperpigmented (Figs. 2 B-D) [10]. Plaque morphea is the most common variant of LoSc affecting the adult population [13].

- Guttate localized morphea - characterized by multiple, yellow-white, small papules with a shiny surface, $<1 \mathrm{~cm}$ in diameter, located primarily on the trunk $[2,4,6]$. Clinically and histopathologically, they may imitate extragenital lichen sclerosus $[6,10]$.

- Atrophoderma of Pasini and Pierini (APP) - regarded as an early abortive form of LoSc associated with a mild course $[4,6]$. It is manifested as oval lesions, greyish brown in colour, either flat or slightly depressed, without skin induration (Fig. 3) [2, 3]. APP-type lesions are more common in children. They often arise symmetrically on the trunk, mainly on the buttocks and lower back, and the proximal areas of the limbs $[2,3,10]$. Atrophoderma of Pasini and Pierini coexists with plaque morphea in $20 \%$ of cases [3]. Occasionally, typical lesions of plaque morphea evolve into APP within a few years of disease onset [4].

\section{Generalized form of localized scleroderma}

- Generalized localized scleroderma - variety diagnosed in 7-9\% of patients, characterized by $\geq 4$ areas of skin induration, $\geq 3 \mathrm{~cm}$ in diameter, in $\geq 2$ anatomic sites $[2,9]$. The lesions are distributed symmetrically within the trunk, thighs and in the lumbosacral region $[2,6]$, and easily distinguishable from the surrounding healthy skin (Figs. 4 A-D) [1, 3]. The disease is characterized by rapid progression and needs to be differentiated from systemic sclerosis. Unlike systemic sclerosis, generalized localized scleroderma is not associated with changes mentacyjne (ryc. 2 B-D) [10]. Twardzina plackowata jest najczęstszą postacią LoSc, która występuje u osób dorosłych [13].

- Twardzina grudkowa (kropelkowa) - liczne, drobne, biało-żółte, połyskujące grudki o średnicy $<1 \mathrm{~cm}$, które lokalizują się przeważnie na tułowiu $[2,4,6]$. Klinicznie i histopatologicznie mogą imitować postać pozagenitalną liszaja twardzinowego [6, 10].

- Twardzina ograniczona pierwotnie zanikowa (atrophoderma of Pasini and Pierini - APP) uważana za powierzchowną, poronną postać LoSc o łagodnym przebiegu [4, 6]. Objawia się owalnymi, szarobrązowymi wykwitami o płaskiej lub nieznacznie zagłębionej powierzchni, bez towarzyszącego stwardnienia (ryc. 3) [2, 3]. Zmiany o charakterze APP są częstsze u dzieci, mają zwykle układ symetryczny i zajmują tułów, szczególnie pośladki i dolną część pleców, oraz proksymalne odcinki kończyn [2, 3, 10]. Atrophoderma of Pasini and Pierini współistnieje w 20\% przypadków z twardziną plackowatą [3]. Niekiedy obserwuje się ewolucję typowych zmian plaque morphea w APP po kilku latach choroby [4].

\section{Twardzina ograniczona uogólniona}

- Twardzina ograniczona uogólniona - odmiana stwierdzana u 7-9\% chorych, cechuje się występowaniem $\geq 4$ ognisk stwardnienia o średnicy $\geq 3 \mathrm{~cm}$, zajmujących $\geq 2$ obszary anatomiczne $[2,9]$. Zmiany lokalizują się symetrycznie w obrębie tułowia, ud i okolicy krzyżowo-lędźwiowej [2, 6]. Wykwity są dobrze odgraniczone od skóry zdrowej (ryc. 4 A-D) $[1,3]$. Choroba cechuje się szybką progresją i wymaga różnicowania z twardziną układową. W przeci- 

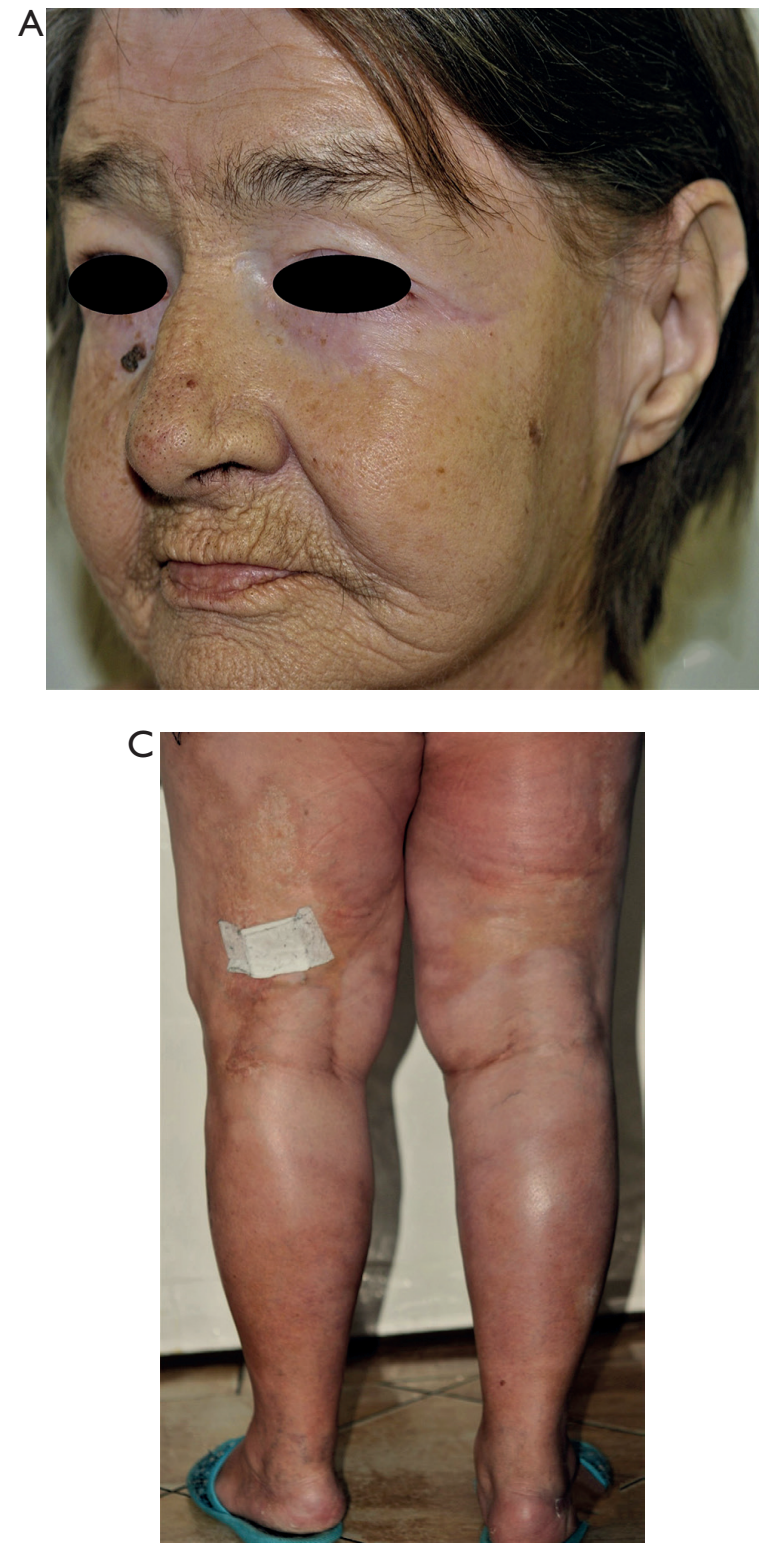

Figure 4 A-D. Generalized morphea

Rycina 4 A-D. Twardzina ograniczona uogólniona

in the nail-bed capillaries, Raynaud phenomenon, ulceration and reabsorption of the phalanges, or facial skin involvement [1,3]. Muscle and joint pain, and fatigue may be present, and laboratory tests may be positive for ANA and eosinophilia [3, 9].

- Disabling pansclerotic scleroderma - a rare (1-2\% of cases) and very severe type of LoSc which is recognized by some authors as an aggressive and mutilating variant of deep morphea [3, 13]. It mainly affects children, and is characterized by extensive sclerotic lesions which lead to contractures involving multiple joints and may progress to disability $[3,10]$. In the early stage of the disease the lesions are limited to the extremities, and later the trunk and face may also be affected [10]. Patients with disabling pansclerotic localized scleroderma have
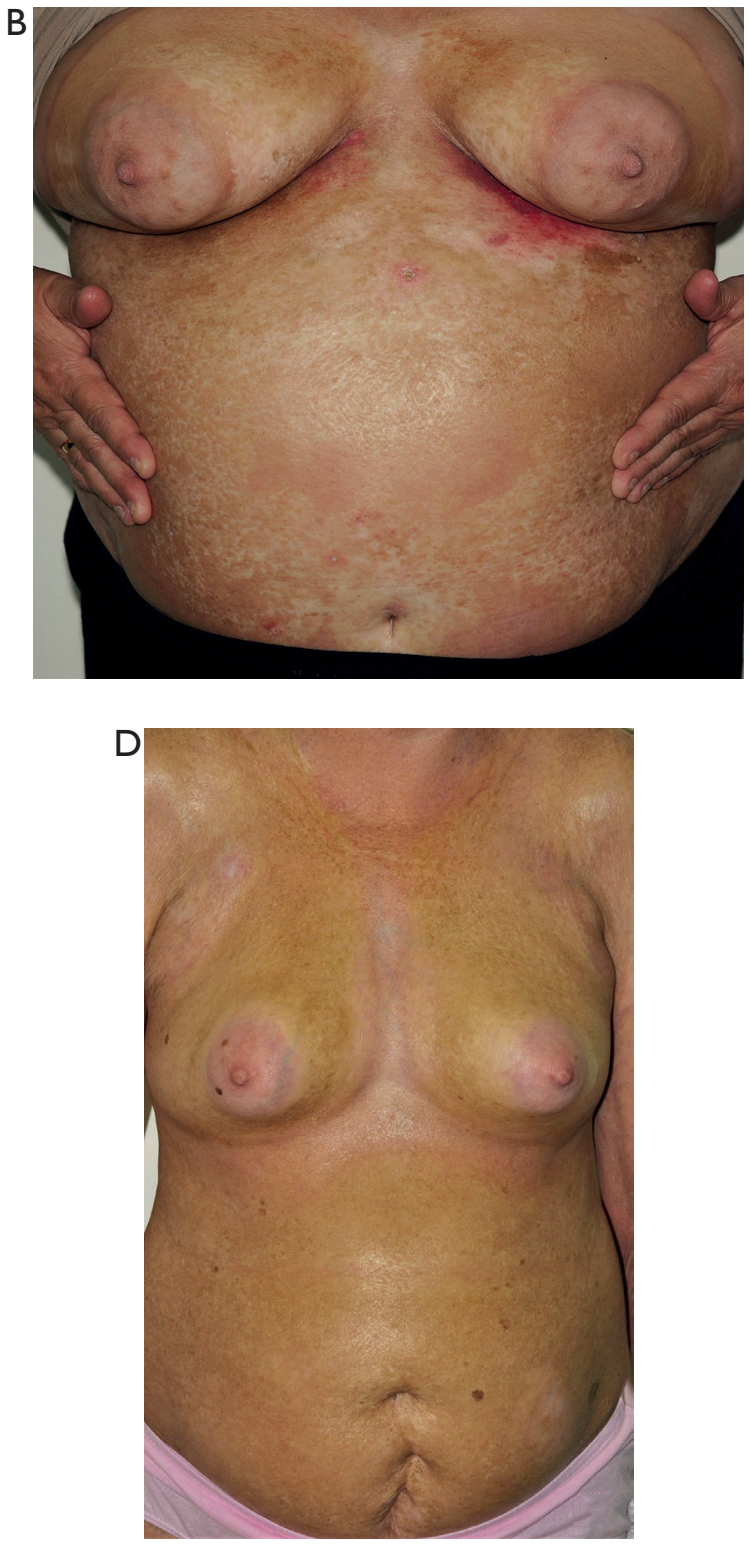

wieństwie do twardziny układowej w przebiegu generalised localized scleroderma nie stwierdza się zmian w badaniu kapilaroskopowym, objawu Raynauda, owrzodzeń i resorpcji paliczków, a także zajęcia skóry twarzy [1,3]. Niekiedy mogą być obecne bóle mięśniowo-stawowe i zmęczenie oraz przeciwciała ANA i eozynofilia w badaniach laboratoryjnych $[3,9]$.

- Twardzina zniekształcająca głęboka - rzadka (1-2\% przypadków), bardzo ciężka odmiana LoSc, uważana przez część autorów za agresywny i okaleczający wariant twardziny głębokiej [3, 13]. Dotyczy głównie dzieci i cechuje się występowaniem rozległych ognisk stwardnień, które powodują przykurcze w wielu stawach i mogą prowadzić do kalectwa $[3,10]$. W początkowym stadium choro- 
an impaired wound healing response. A potential consequence is the development of ulcerations which may lead to squamous cell carcinoma (SCC) $[3,9,13]$.

- Eosinophilic fasciitis (Shulman's syndrome) a type of scleroderma occurring predominantly in young men [10]. It is characterized by symmetrical induration of the skin of the extremities which may be preceded by trauma or intensive physical exercise $[2,6]$. In the initial stage of eosinophilic fasciitis, the skin appears doughy and swollen, but soon becomes hard and firmly bound to the underlying tissues [3]. Characteristic manifestations of Shulman's syndrome include "orange peel" appearance and "groove sign" on the skin $[2,6]$. Coexisting lesions typical of plaque morphea (mainly located on the trunk) are observed in $30 \%$ of patients diagnosed with eosinophilic fasciitis [3]. In addition to skin lesions, some patients develop extracutaneous manifestations including synovitis, tenosynovitis, contractures, and carpal tunnel syndrome [3]. Characteristic laboratory findings include eosinophilia (not regarded as a diagnostic criterion), hypergammaglobulinaemia and elevated ESR. Some patients develop abnormalities manifested as aplastic and haemolytic anaemia, and thrombocytopaenia [3]. Shulman's syndrome may be a paraneoplastic sign [14, 15].

\section{Linear form of localized scleroderma}

- Linear localized scleroderma - a disease mainly affecting children, with peak incidence seen at the age of 13 years $[1,16,17]$. A retrospective study conducted in a group of 750 paediatric patients revealed linear localized scleroderma in $65 \%$ of all cases [18]. The disorder is characterized by linear, band-like sclerotic lesions occurring along Blaschko's lines on the extremities (Figs. 5 A-C) $[3,4]$. The lesions are typically unilateral and heal, leaving behind areas of hyperpigmentation in mild cases of the disease [1-4]. Severe forms of linear localized scleroderma lead to limited joint mobility and growth disorders [10]. Linear localized scleroderma recurs frequently and regardless of the age of onset [19]. ANA are detected in half of all cases $[16,20]$.

- Localized scleroderma en coup de sabre (ECDS) - typically presents with a linear cutaneous induration extending in the midline from the eyebrows onto the scalp (Fig. $6 \mathrm{~A}$ ). The lesion is usually unilateral, but rare bilateral cases have also been reported [4]. Localized scleroderma en coup de sabre leads to cicatricial alopecia (Fig. 6 B) [2]. In $20 \%$ of patients the disease may involve the central nervous system (CNS) and cause ophthalmological complications (epilepsy, migraine, neuralgia, enophthalmia, oculomotor nerve palsy, by zmiany obejmują kończyny, a z czasem może dochodzić do zajęcia skóry tułowia i twarzy [10]. $\mathrm{U}$ pacjentów $\mathrm{z}$ disabling pansclerotic localized scleroderma następuje upośledzenie procesu gojenia się ran, co sprzyja powstawaniu owrzodzeń, na podłożu których może rozwinąć się rak kolczystokomórkowy (squamous cell carcinoma - SCC) $[3,9,13]$.

- Eozynofilowe zapalenie powięzi (zespół Shulmana) - typ twardziny występujący przeważnie u młodych mężczyzn [10]. Cechuje się symetrycznym stwardnieniem skóry kończyn, które może być poprzedzone urazem lub intensywnym wysiłkiem fizycznym [2, 6]. W początkowej fazie eozynofilowego zapalenia powięzi skóra objęta procesem chorobowym jest ciastowata, obrzęknięta, po czym szybko twardnieje i ściśle przylega do głębiej położonych tkanek [3]. Typowe dla zespołu Shulmana są objawy „skórki pomarańczy" oraz „bruzd i rowków” [2, 6]. W 30\% przypadków obserwuje się współwystępowanie zmian o charakterze twardziny plackowatej (głównie w obrębie tułowia) [3]. Poza zmianami skórnymi u części pacjentów mogą wystąpić objawy pozaskórne, takie jak zapalenie błony maziowej i kaletki stawowej, przykurcze, zespół cieśni nadgarstka [3]. W badaniach laboratoryjnych obserwuje się eozynofilię (nie stanowi kryterium rozpoznania), hipergammaglobulinemię oraz podwyższone OB. U części pacjentów dochodzi do zaburzeń w postaci anemii aplastycznej i hemolitycznej oraz trombocytopenii [3]. Zespół Schulmana może stanowić objaw paraneoplastyczny [14, 15].

\section{Twardzina linijna}

- Twardzina linijna kończyn - choroba występuje głównie u dzieci, a szczyt zachorowań przypada na 13. rok życia $[1,16,17]$. W badaniu retrospektywnym przeprowadzonym w grupie 750 pacjentów pediatrycznych wykazano, że linear localized scleroderma występowała w $65 \%$ przypadków [18]. Schorzenie charakteryzuje się obecnością linijnych, pasmowatych stwardnień biegnących wzdłuż linii Blaschko na kończynach (ryc. 5 A-C) [3, 4]. Zmiany mają przeważnie układ jednostronny i w łagodnych przypadkach ustępują z pozostawieniem przebarwień [1-4]. Ciężkie odmiany twardziny linijnej prowadzą do ograniczenia ruchomości w stawach i zaburzeń wzrostu [10]. Nawroty choroby są częste i niezależne od wieku jej wystąpienia [19]. W połowie przypadków stwierdza się obecność przeciwciał ANA [16, 20].

- Twardzina typu cięcia szablą (en coup de sabre ECDS) - choroba przebiega z linijnym stwardnieniem w linii pośrodkowej ciała od wysokości brwi do owłosionej skóry głowy (ryc. 6 A). Zmiana jest przeważnie pojedyncza, ale opisywano przypadki występowania linii podwójnych [4]. Twardzina typu cięcia szablą prowadzi do łysienia bliznowaciejącego (ryc. 6 B) [2]. U $20 \%$ chorych może przebiegać z zajęciem ośrod- 

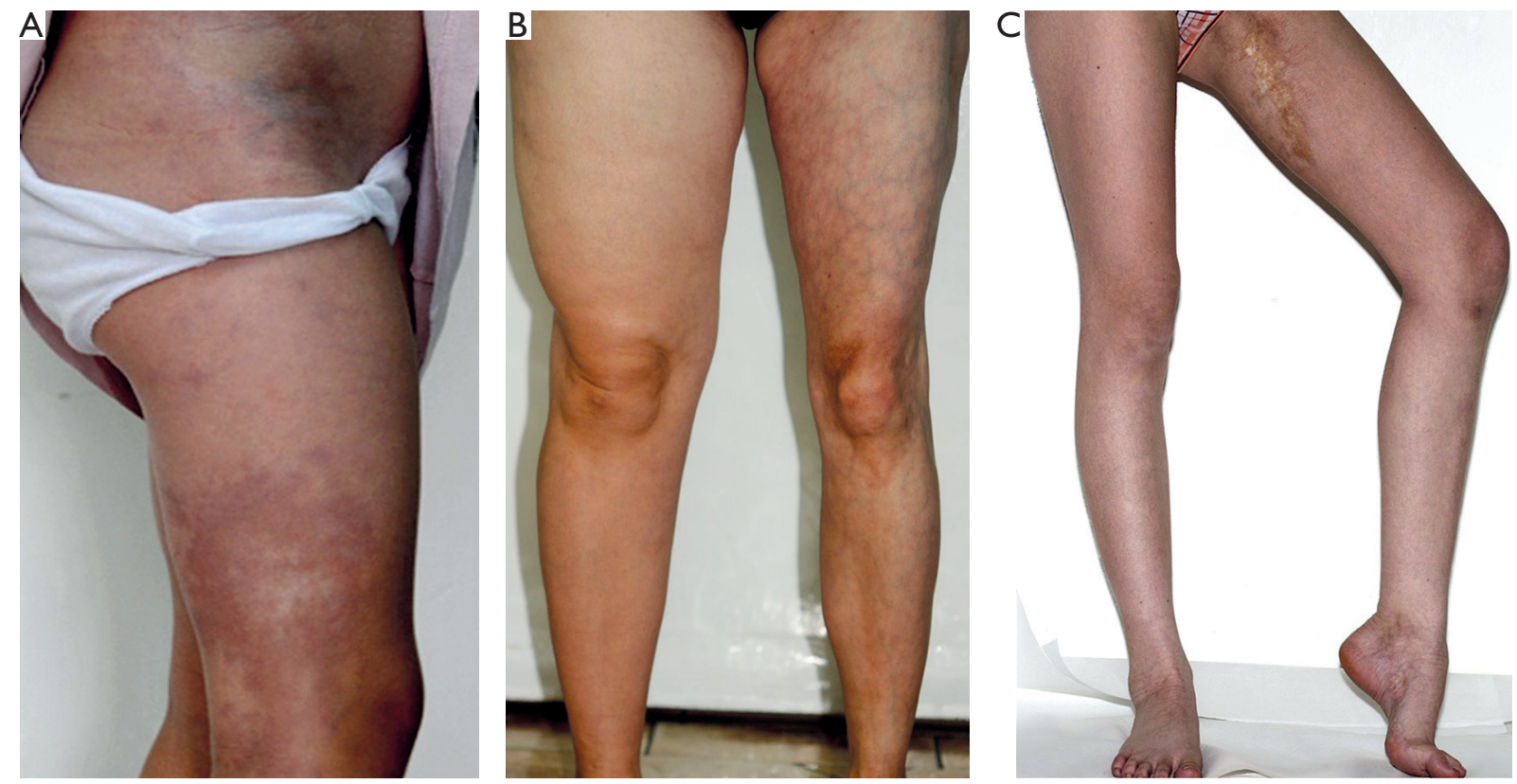

Figure 5. Linear scleroderma on the lower extremities. Photographs $5 \mathrm{~A}$ and $\mathrm{C}$ courtesy of Barttomiej Wawrzycki, PhD, MD Rycina 5. Twardzina linijna kończyn dolnych. Fotografie 5 A i C dzięki uprzejmości dr. n. med. Bartłomieja Wawrzyckiego

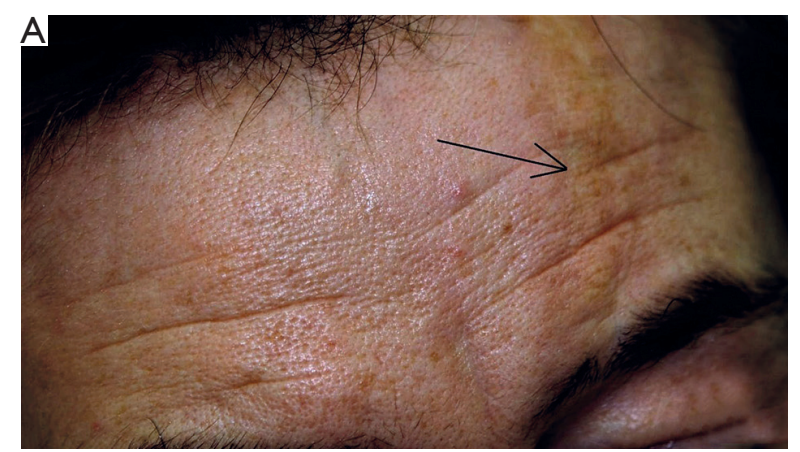

Figure 6. A - Morphea en coup de sabre. B - Patch of cicatricial alopecia. Photograph 6 B courtesy of Michał Adamczyk, MD

Rycina 6. A - Twardzina typu cięcia szablq. B - Ognisko łysienia bliznowaciejq̨cego. Fotografia 6 B dzięki uprzejmości lek. Michała Adamczyka

Horner's syndrome), which is why magnetic resonance imaging (MRI) of the head is recommended in every case $[2,3,21]$. Localized scleroderma en coup de sabre is occasionally associated with progressive facial hemiatrophy; the disorders coexist in $20-40 \%$ of cases [1, 2].

- Progressive facial hemiatrophy (PFH, Parry-Romberg syndrome) - a rare variant of LoSc which starts mainly in childhood ( $<10$ years old), but it may occur at any age [23]. It is characterized by facial hemiatrophy (often on the left side) affecting

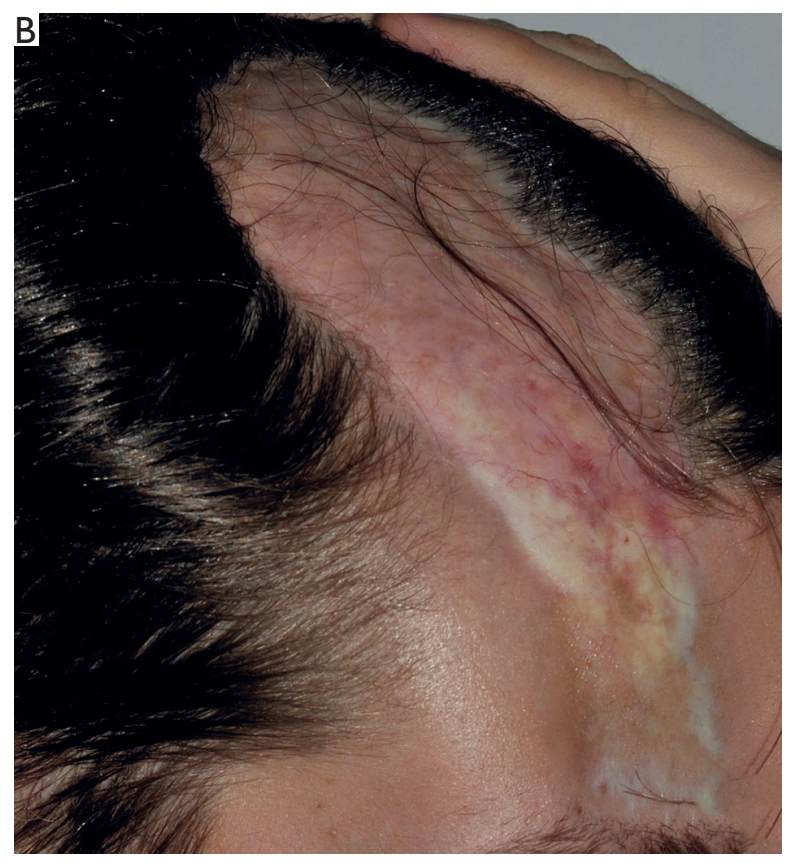

kowego układu nerwowego (OUN) i narządu wzroku (padaczka, migrena, neuralgia, zapadnięcie gałki ocznej, porażenie nerwu okoruchowego, zespół Hornera), dlatego w każdym przypadku należy rozważyć wykonanie rezonansu magnetycznego (MRI) głowy [2, 3, 21, 22]. Twardzina typu cięcia szablą jest niekiedy ściśle związana z postępującym zanikiem połowiczym twarzy; schorzenia współwystępują w 20-40\% przypadków [1, 2].

- Postępujący zanik połowiczy twarzy (PFH, Parry-Romberg syndrome) - rzadka odmiana LoSc, 

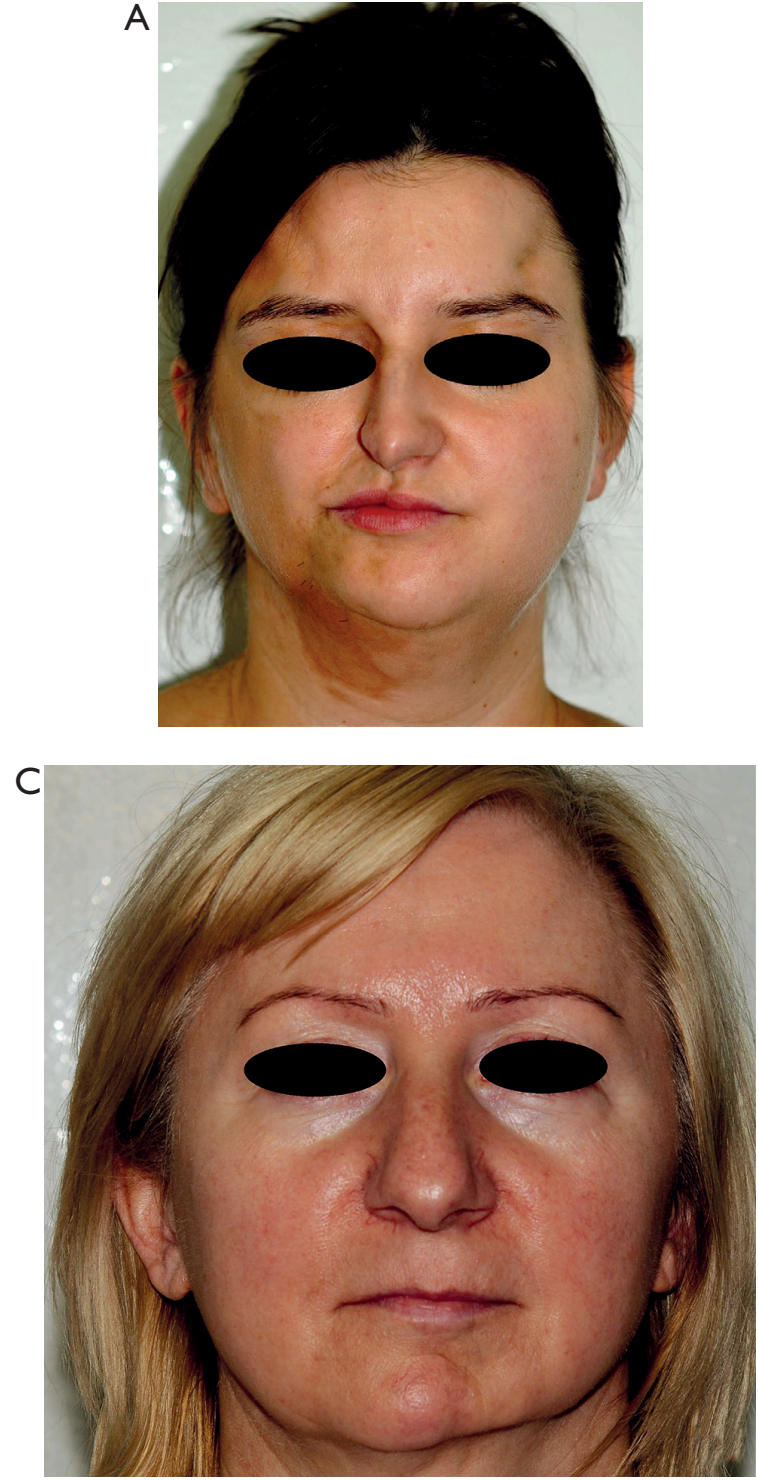
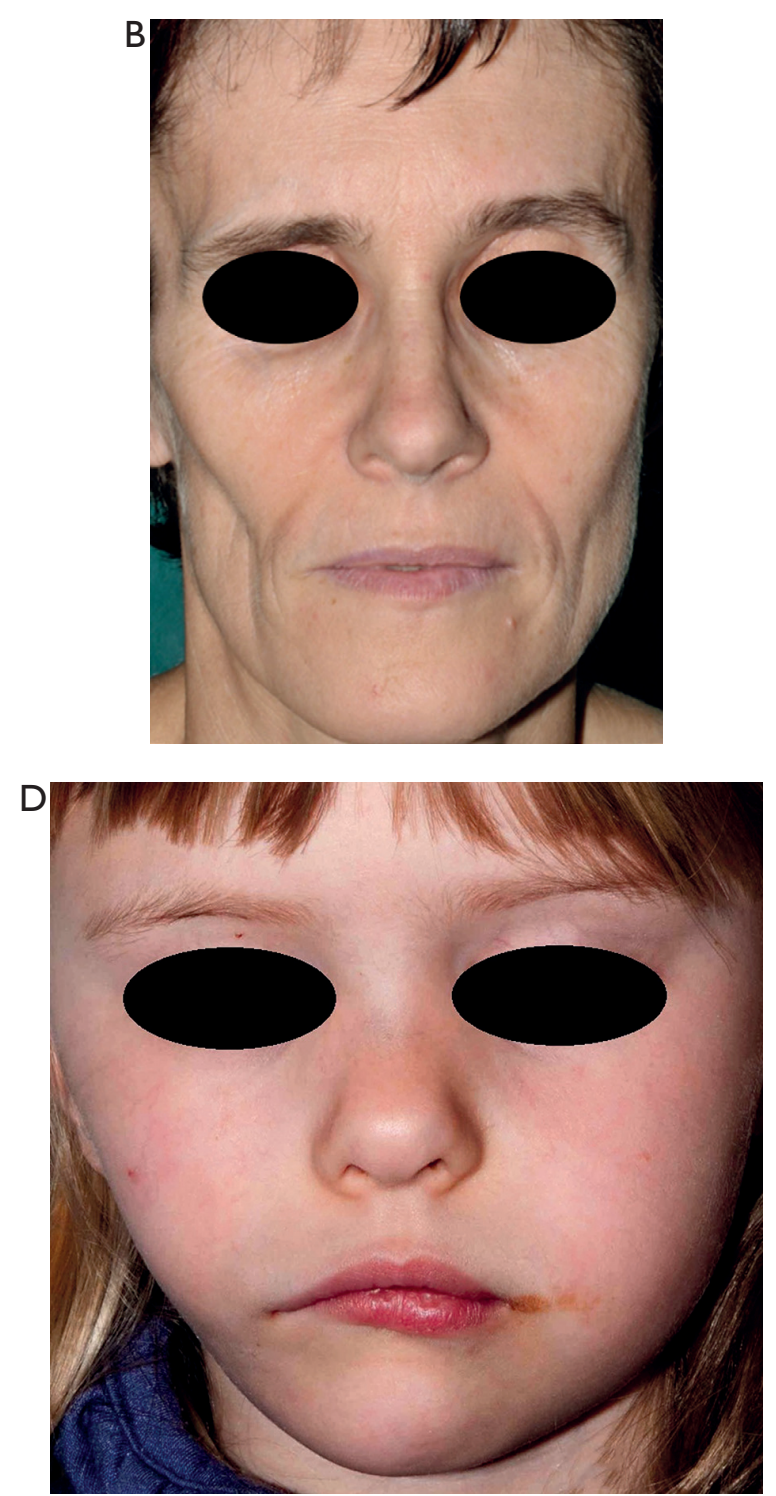

Figure 7. A, B, D - Parry-Romberg syndrome (right-sided). C - Parry-Romberg syndrome (left-sided). Photographs 7 B and D courtesy of Bartłomiej Wawrzycki, PhD, MD

Rycina 7. A, B, D - Postępujq̨cy zanik połowiczy twarzy (lokalizacja prawostronna). C - Postępujący zanik połowiczy twarzy (lokalizacja lewostronna). Fotografie 7 B i D dzięki uprzejmości dr. n. med. Bartłomieja Wawrzyckiego

the dermis, subcutaneous tissue and underlying bone (Figs. 7 A-C) [10, 24]. Facial asymmetry is particularly prominent when the disease begins in childhood and inhibits normal development of the affected structures (Fig. 7 D) [4]. The typical course of Parry-Romberg syndrome is slow progression over 2-20 years [1]. Features distinguishing PFH from ECDS are listed in Table 4 [1, 2]. Antinuclear antibodies (ANA) are detected in $50 \%$ of patients. Neurological disorders including migraine, trigeminal nerve palsy and epilepsy occur in $20 \%$, and ophthalmological complications in $15 \%$ of patients [25]. Sometimes the disease is associated with hair loss and premature greying [24]. Maxillary deformity may develop in a proportion of cases, mani- rozpoczyna się głównie u dzieci poniżej 10. roku życia, ale może pojawić się w każdym wieku [23]. Charakteryzuje się zanikiem połowy twarzy (nieco częściej lewej strony), który obejmuje skórę, tkankę podskórną i kości (ryc. 7 A-C) [10, 24]. Asymetria twarzy jest szczególnie wyraźna, gdy choroba ma początek w wieku dziecięcym i hamuje prawidłowe kształtowanie zajętych struktur (ryc. 7 D) [4]. Rozwój PFH jest powolny i trwa 2-20 lat [1]. Cechy odróżniające PFH od ECDS przedstawiono w tabeli 4 [1, 2]. U 50\% pacjentów obecne są przeciwciała przeciwjądrowe ANA. Zaburzenia neurologiczne w postaci migreny, porażenia nerwu trójdzielnego i padaczki występują u $20 \%$ chorych, z kolei powikłania okulistyczne u 15\% [25]. Niekiedy dochodzi 
Table 4. Differentiation of scleroderma en coup de sabre and progressive facial hemiatrophy (Parry-Romberg syndrome) [I, 2 I ] Tabela 4. Różnicowanie twardziny typu cięcia szablą i postępujq̨cego zaniku połowiczego twarzy [1, 21]

$\begin{array}{lll}\text { Feature/Cecha } & \text { En coup de sabre/Typu cięcia szablą } & \begin{array}{c}\text { Parry-Romberg syndrome/ } \\ \text { zespoł Parry'ego-Romberga }\end{array} \\ \begin{array}{lll}\text { type of skin lesions/charakter zmian skórnych } & \text { sclerotic/stwardniałe } & \text { atrophic/atroficzne } \\ \hline \text { primary site/lokalizacja początkowa } & \text { forehead, scalp/czoło, owłosiona skóra głowy } & \text { cheek, nose/policzki, nos } \\ \hline \text { expansion of lesions/szerzenie się zmian } & \begin{array}{l}\text { do not extend below the eyebrow/nie } \\ \text { przekraczają czoła }\end{array} & \begin{array}{l}\text { affect lower face/obejmują dolne } \\ \text { partie twarzy }\end{array} \\ \hline \begin{array}{ll}\text { internal organ involvement/zajęcie narządów } \\ \text { wewnętrznych }\end{array} & + & - \\ \hline \text { CNS involvement/zajęcie OUN } & + & +\end{array}\end{array}$

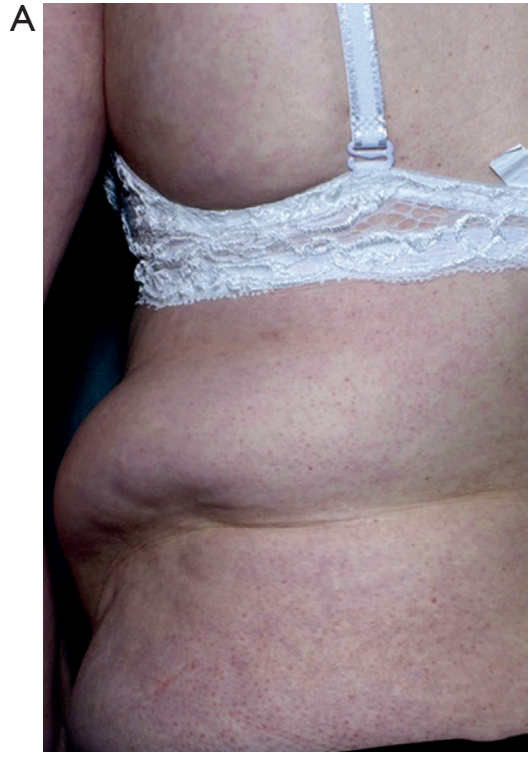

festing as dental root atrophy, delayed eruption and malocclusion [3]. Lesions similar to progressive hemifacial atrophy sometimes occur in other conditions such as lupus profundus and lipodystrophy [26].

\section{Deep localized scleroderma}

Deep localized scleroderma is a rare form of LoSc $(<5 \%)$ characterized by the presence of deep sclerotic lesions affecting the muscles, fasciae, subcutaneous tissue and deeper layers of the dermis (Figs. 8 A, B) [3, 6]. The lesions typically arise symmetrically, and are seen over the upper back, mainly in the paravertebral line $[1,2]$. Apart from cutaneous manifestations, no other subjecti ve symptoms or internal organ involvement are noted [1].

\section{Mixed form of localized scleroderma}

Mixed form of localized scleroderma diagnosed in approximately $15 \%$ of patients (mostly children) and characterized by a combination of $\geq 2$ varieties

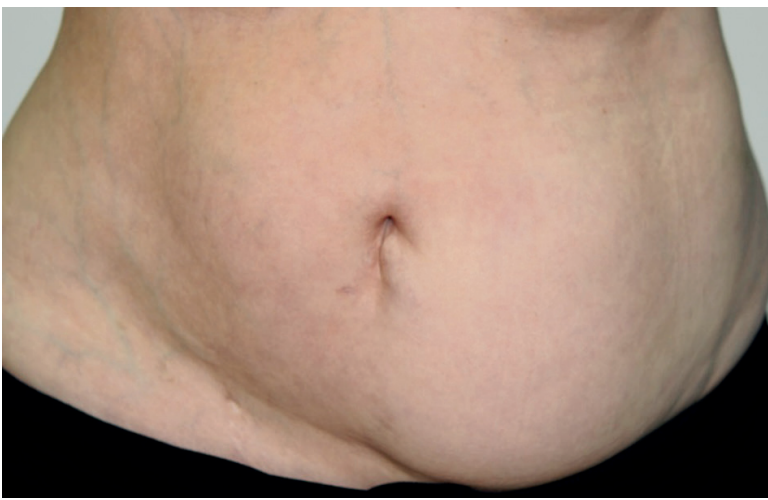

Figure 8. Deep morphea. Photograph 8 A courtesy of Bartłomiej Wawrzycki, PhD, MD

Rycina 8. Twardzina ograniczona glęboka. Fotografia 8 A dzięki Rrzejmości dr. n. med. Bartłomieja Wawrzyckiego

do utraty włosów na głowie oraz ich przedwczesnego siwienia [24]. W części przypadków występuje deformacja szczęki, co objawia się atrofią korzeni zębowych, opóźnionym wyrzynaniem zębów oraz wadami zgryzu [3]. Podobne zmiany o charakterze postępującego połowiczego zaniku skóry twarzy mogą wystąpić w przebiegu odmiany podskórnej (głębokiej) tocznia rumieniowatego skórnego oraz lipodystrofii [26].

\section{Twardzina głęboka}

Twardzina głęboka jest rzadko spotykaną postacią LoSc $(<5 \%)$, charakteryzuje się obecnością głębokich stwardnień, które obejmują mięśnie, powięź, tkankę podskórną oraz głębsze warstwy skóry właściwej (ryc. 8 A, B) [3, 6]. Zmiany są przeważnie symetryczne i zajmują górną część pleców, zwłaszcza w linii przykręgosłupowej [1, 2]. Wykwitom skórnym nie towarzyszą żadne objawy subiektywne ani zajęcie narządów wewnętrznych [1].

\section{Twardzina mieszana}

Dotyczy ok. 15\% pacjentów (przeważnie dzieci) i stanowi kombinację $\geq 2$ odmian LoSc, zwykle jest to twar- 


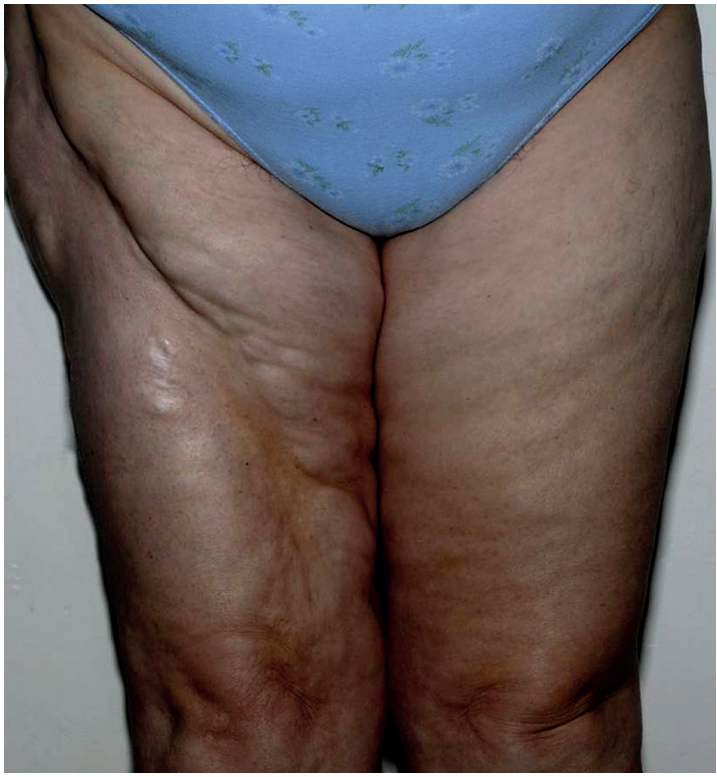

Figure 9. Mixed (deep and linear) morphea. Courtesy of Bartłomiej Wawrzycki, PhD, MD

Rycina 9. Twardzina ograniczona mieszana (głęboka i linijna). Dzięki uprzejmości dr. n. med. Bartłomieja Wawrzyckiego

of LoSc, typically linear LoSc + plaque morphea and linear LoSc + generalized LoSc [2, 9] (Fig. 9).

\section{Bullous localized scleroderma}

Bullous localized scleroderma is a casuistic form manifested by the development of subepidermal bullae within sclerotic plaques, mainly on the skin of the lower extremities and abdomen (Fig. 10). The eruption of bullae is most likely induced by morphea plaques exerting pressure on lymphatic vessels [27] Bullous lesions may occur in every clinical form of LoSc.

\section{METHODS OF ASSESSING ACTIVITY/SEVERITY OF THE DISEASE AND TISSUE DAMAGE}

A crucial aspect in evaluating patients with LoSc is the assessment of activity/severity of the disease and extent of tissue damage. A precise analysis of these parameters is important for monitoring the course of the disease and making therapeutic decisions. The extent of tissue damage and severity/activity of the disease are assessed by means of imaging techniques including ultrasonography, laser Doppler flowmetry, electromyography, MRI, thermography and durometry. The Localized Scleroderma Clinical and Ultrasound Study Group has proposed and validated two indices: LS Skin Severity Index (LoSSI) for the assessment of disease activity/severity, and LS Skin Damage Index (LoSDI) for the assessment of tissue damage, recommending the use of the indices in combination with a general patient assessment (phy-

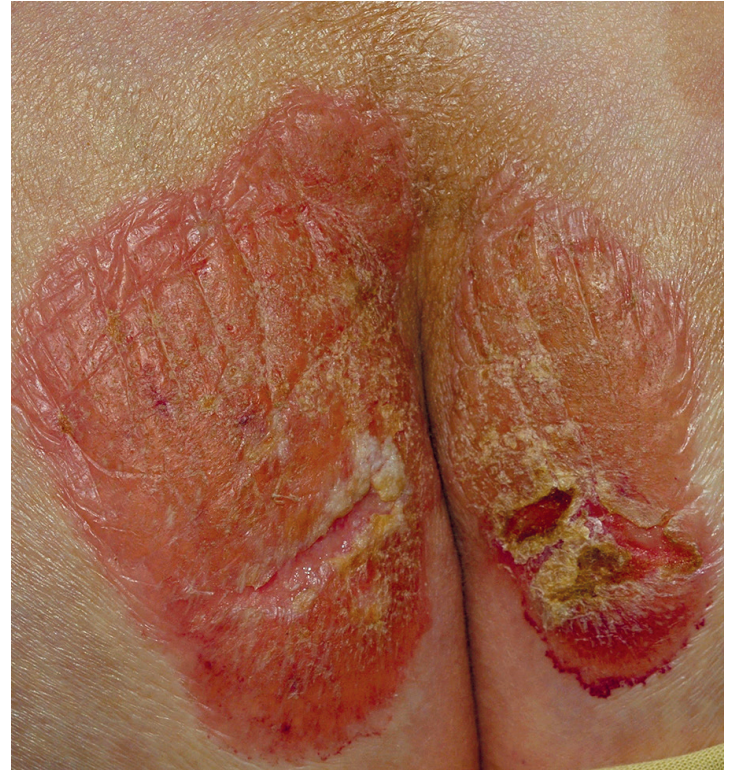

Figure 10. Bullous morphea. Courtesy of Michał Adamczyk, MD Rycina 10. Twardzina ograniczona pęcherzowa. Dzięki uprzejmości lek. Michała Adamczyka

dzina linijna + twardzina plackowata oraz twardzina linijna + twardzina ograniczona uogólniona [2, 9] (ryc. 9).

\section{Twardzina pęcherzowa}

Twardzina pęcherzowa jest postacią kazuistyczną, objawia się powstawaniem podnaskórkowych pęcherzy w obrębie blaszek twardzinowych, głównie na skórze kończyn dolnych i brzucha (ryc. 10). Wysiew pęcherzy jest najprawdopodobniej indukowany uciskiem blaszek morphea na naczynia limfatyczne [27]. Zmiany pęcherzowe mogą wystąpić w przebiegu każdej z postaci klinicznych LoSc.

\section{METODY OCENY AKTYWNOŚCI LUB NASILENIA CHOROBY I USZKODZENIA TKANEK}

Istotnym aspektem ewaluacji pacjentów z LoSc jest ocena aktywności lub nasilenia procesu chorobowego oraz stopnia uszkodzenia tkanek. Precyzyjna analiza powyższych parametrów jest istotna dla monitorowania przebiegu choroby oraz podejmowania decyzji o rodzaju terapii. $W$ tym celu stosowane są metody obrazowe: ultrasonografia, laserowy przepływomierz dopplerowski, elektromiografia, MRI, termografia oraz durometria. Kliniczna i Ultrasonograficzna Grupa Badawcza Twardziny Ograniczonej (Localized Scleroderma Clinical and Ultrasound Study Group) zaproponowała i zwalidowała wskaźnik aktywności lub nasilenia choroby (LS Skin Severity Index - LoSSI) oraz wskaźnik uszkodzenia tkanek (LS Skin Damage Index - LoSDI), rekomendując stosowanie powyższych indeksów w połączeniu z ogólną oceną lekarską (physican's glo- 
sician's global assessment - PGA). The combination of the three indices is referred to as LS Cutaneous Assessment Tool (LoSCAT) and represents a promising tool in the evaluation of patients with LoSc owing to the repeatability and consistency of assessment. Another (unvalidated) scale used for the assessment of patients with LoSc is DIET which takes into account four parameters: dyspigmentation (D), induration (I), erythema (E) and telangiectasias (T) $[5,28]$. Each item is given a score on a scale from 0 (no symptom) to 3 (severe symptom). DIET has a number of limitations such as failure to take into account the extent of cutaneous lesions and rare incidence of telangiectasias typical of SSc [28].

- Ultrasonography (USG) is an imaging method used for evaluating sites affected by the disease and homolateral areas of normal skin. USG appears to be a promising evaluation tool, however it requires technical standardization before it can be used for routine assessment of severity/activity of the disease. Ultrasonography demonstrates high sensitivity and repeatability, and corresponds well with clinical assessment results. Moreover, unlike MRI, it does not require sedation in the evaluation of children [29]. Ultrasound heads in the frequency range of 10-25 MHz range [30] are used in the diagnostics of localized scleroderma. The higher the frequency, the higher the resolution of the ultrasonography unit but, at the same time, the smaller the depth of wave penetration. Heads with a higher frequency ( $\geq 20 \mathrm{MHz}$; high frequency ultrasonography - HF-US) are often used for imaging the dermis, whereas lower frequencies, in the range of $7-10 \mathrm{MHz}$, are useful in imaging the subcutaneous tissue. The ultrasound image is affected by the clinical stage of the disease. Skin thickening and reduced echogenicity are observed during the inflammatory (active) stage, resulting from the presence of inflammatory infiltrations. The sclerotic phase is characterized by skin thickening and hyperechogenicity, as opposed to the atrophic phase which is associated with skin thinning and normal echogenicity. In their ultrasonographic assessment of LoSc lesions Li et al. found that the active phase of the disease was characterized by an increased blood flow and increased tissue echogenicity [29]. In addition, the ultrasonographic assessment of lesions with morphological features of LoSc performed by Liebling et al. revealed subcutaneous tissue atrophy both in the active and inactive phases of the disease. The authors suggested that the normalization of echogenicity within the dermis correlated with a clinical improvement, whereas tissue thinning or thickening might indicate the active phase of the disease $[29,31]$. Wortsman et al. presented sonographic criteria for the assessment of LoSc activity. The active form of the disease is characterized by the presence of $\geq 2$ of 3 manifestations including bal assessment - PGA). Kombinacja trzech wymienionych wskaźników nosi nazwę LS Cutaneous Assessment Tool (LoSCAT) i jest obiecującym narzędziem ewaluacji pacjentów z LoSc, które cechuje się powtarzalnością i zgodnością ocen. Inną, niezwalidowaną skalą oceny pacjentów z LoSc jest DIET, która uwzględnia następujące parametry: zaburzenia pigmentacji (D - dispigmentation), stwardnienie (I - induration), rumień (E - erythema) i teleangiektazje ( $\mathrm{T}$ - teleangiectasia) $[5,28]$. Każda z cech jest punktowana w skali od 0 (brak objawu) do 3 (nasilony objaw). Ograniczeniem stosowania DIET jest nieuwzględnienie rozległości zmian skórnych oraz rzadkie występowanie teleangiektazji typowych dla SSc [28].

- Ultrasonografia (USG) - metoda obrazowa stosowana zarówno do oceny zmian chorobowych, jak i skóry prawidłowej w jednoimiennej lokalizacji. Ta metoda badania wydaje się obiecująca, ale wymaga technicznej standaryzacji, zanim będzie mogła być stosowana rutynowo do oceny nasilenia lub aktywności procesu chorobowego. Cechuje się dużą czułością i powtarzalnością, dobrze koreluje z wynikiem badania klinicznego i w przeciwieństwie do MRI nie wymaga stosowania znieczulenia u dzieci [29]. W diagnostyce twardziny ograniczonej stosuje się głowice o częstotliwości 10-25 $\mathrm{MHz}$ [30]. Im większa jest częstotliwość głowicy, tym większa rozdzielczość urządzenia, ale jednocześnie płytsza penetracja fali. W celu zobrazowania skóry właściwej stosuje się zwykle głowice o wyższej częstotliwości $\geq 20 \mathrm{MHz}$ (high frequency ultrasonography - HF-US), natomiast częstotliwości rzędu 7-10 MHz uwidaczniają tkankę podskórną. Na obraz ultrasonograficzny ma wpływ kliniczna faza schorzenia. W okresie zapalnym (aktywnym) obserwuje się pogrubienie skóry i obniżenie jej echogeniczności, co wynika z obecności nacieków zapalnych. Faza stwardnienia charakteryzuje się pogrubieniem i hiperechogenicznością skóry, natomiast faza atroficzna przebiega z jej ścieńczeniem i normoechogenicznością. Li i wsp., oceniając w USG ogniska LoSc, stwierdzili, że aktywna faza choroby cechowała się wzmożonym przekrwieniem i echogenicznością tkanek [29]. Liebling i wsp., badając ultrasonograficznie zmiany o morfologii LoSc, zauważyli, że zanik tkanki podskórnej był obecny zarówno w fazie aktywnej, jak i nieaktywnej choroby. Autorzy zasugerowali, że normalizacja echogeniczności w obrębie skóry właściwej korelowała z poprawą stanu klinicznego, natomiast ścieńczenie lub zgrubienie tkanek mogło wskazywać na aktywną fazę choroby [29, 31]. Wortsman i wsp. przedstawili sonograficzne kryteria oceny aktywności LoSc. Aktywna postać choroby charakteryzuje się obecnością $\geq 2$ z 3 następujących objawów: wzmożona grubość skóry 
increased dermal thickness, decreased dermal echogenicity and increased subcutaneous tissue echogenicity [32]. A sonographic marker of LoSc activity is an increase in cutaneous or subcutaneous blood flow. In the inactive phase of the disease the above criteria are not fulfilled. Atrophic forms of LoSc are distinct for a decreased dermal or subcutaneous thickness and the absence of increased blood flow in the skin [32].

- Laser Doppler flowmetry (LDF) is a non-invasive method for the measurement of cutaneous microcirculation, particularly in inflammatory diseases and neuropathies [33]. It has high negative and positive predictive values of $94 \%$ and $84 \%$, respectively [34]. A negative LDF result (i.e. no difference in blood flow between affected and unaffected skin) correlates with a good therapeutic outcome, while a positive result (i.e. increased blood flow within affected skin sites) reflects the active form of the disease [34]. In some cases a slight increase in blood flow found in inactive lesions may suggest persistent changes in the microcirculation or active inflammatory process which is not detectable by clinical examination yet [33]. Murray et al. report that an increased perfusion in affected sites may be a result of decreased skin thickness within the plaques, which increases vascular thickness and facilitates their visualization [35].

- Infrared thermography (IRT) is a non-invasive method for assessing the activity of localized scleroderma lesions. It demonstrates a high sensitivity (92\%) and a slightly lower specificity $(68 \%)$ which is responsible for falsely positive results within old inactive lesions [36, 37]. The main inconveniences of the method are the need to ensure controlled temperature during the examination and the lack of possibility to assess the morphology of lesions [32]. Thermography is performed within affected sites and, for comparative purposes, in a homolateral area of healthy skin. The result is considered positive when the difference in temperature between the compared sites is $>0.5^{\circ} \mathrm{C}[36]$.

- Magnetic resonance imaging (MRI) and computed tomography (CT) are two imaging methods used in more severe cases of LoSc involving the skin, subcutaneous tissue, muscles, fasciae and bones [38]. On account of frequent CNS and eye involvement patients with localized scleroderma en coup de sabre and progressive facial hemiatrophy require individual assessment to determine whether MRI and CT are warranted $[2,3]$. The most commonly diagnosed changes include calcifications seen on CT images and high-intensity MR signals [39]. The disadvantages of the two methods include their high cost, exposure to ra- właściwej, obniżona echogeniczność skóry właściwej, wzmożona echogeniczność tkanki podskórnej [32]. Sonograficznym markerem aktywności LoSc jest zwiększony przepływ krwi w obrębie skóry lub tkanki podskórnej. W postaci nieaktywnej powyższe kryteria nie są spełnione. Formy atroficzne charakteryzuje zmniejszona grubość skóry lub tkanki podskórnej i brak zwiększonego skórnego przepływu krwi [32].

- Laserowy przepływomierz dopplerowski (laser Doppler flowmetry - LDF) - służy do nieinwazyjnej oceny mikrokrążenia w obrębie skóry, szczególnie w chorobach zapalnych i neuropatiach [33]. Cechuje się dużą negatywną i pozytywną wartością predykcyjną, odpowiednio 94\% i 84\% [34]. Negatywny wynik LDF (brak różnic w przepływie krwi między skórą zmienioną chorobowo i niezmienioną) koreluje z dobrym efektem terapeutycznym, a wynik pozytywny (zwiększony przepływ krwi w obrębie zmian chorobowych) odzwierciedla aktywną postać choroby [34]. W części przypadków nieznaczny wzrost przepływu krwi w zmianach nieaktywnych wskazuje na przetrwałe zmiany w mikrokrążeniu lub obecność procesu zapalnego, który nie ma jeszcze wykładników w badaniu klinicznym [33]. Murray i wsp. uważają, że zwiększony przepływ krwi w obrębie zmienionej chorobowo skóry może być wynikiem zmniejszenia jej grubości w obrębie wykwitów, co powoduje zagęszczenie naczyń i ułatwia ich uwidocznienie [35].

- Termografia (infrared thermography - IRT) - nieinwazyjna metoda oceny aktywności zmian twardzinowych. Wykazuje dużą czułość (92\%) i nieco mniejszą swoistość (68\%), za którą odpowiedzialne są fałszywie dodatnie wyniki w obrębie starych, nieaktywnych zmian $[36,37]$. Niedogodności metody wynikają z konieczności zapewnienia kontrolowanej temperatury badania oraz braku oceny morfologii zmian [32]. Termografię przeprowadza się w obrębie ognisk chorobowych i porównawczo w obszarze prawidłowej skóry w jednoimiennej lokalizacji. Za wynik pozytywny przyjmuje się różnicę temperatur wynoszącą $>0,5^{\circ} \mathrm{C}$ pomiędzy konfrontowanymi obszarami [36].

- Rezonans magnetyczny i tomografia komputerowa (magnetic resonance imaging - MRI, computed tomography - CT) - metody obrazowania stosowane w cięższych przypadkach LoSc, które przebiegają z zajęciem skóry, tkanki podskórnej, mięśni, powięzi i kości [38]. Pacjenci z twardziną typu cięcia szablą oraz z postępującym zanikiem połowiczym twarzy wymagają indywidualnej oceny pod kątem wykonania powyższych badań ze względu na częste zajęcie OUN i narządu wzroku $[2,3]$. Do najczęstszych zmian należą zwapnienia w CT oraz sygnały o dużej intensywności w MRI [39]. Wadą obu metod jest ich koszt, 
diation and the need for sedation in paediatric patients [29].

- Electromyography (EMG) is a promising technique which can be used in the diagnostic assessment of electric activity of muscles and peripheral nerves in linear scleroderma. The first EMG-based studies evaluating muscle tissue involvement were conducted by Magalhaes et al. in 9 paediatric patients with linear scleroderma (2 with PRS, 7 with linear scleroderma of extremities) [40]. The authors concluded that muscle abnormalities might be related to secondary involvement of the peripheral nervous system [40].

- Computerized skin score (CSS) is a method described for the first time by Zulian et al. in 2007 [28]. The method is based on the application of transparent film dressing (Tegaderm) to affected skin and colour-marking of the area of induration and erythema/lilac ring after the palpation of lesions [41]. In the next step, the Tegaderm is transferred onto a sheet of paper which is placed in a special scanner and digitalized [28]. In this form the image is analyzed by a computer system which evaluates the ratio of the inflammatory component to the sclerotic component in affected skin areas [41]. The software also allows a precise calculation of the patient's body surface area (BSA) affected by scleroderma after entering the patient's height and body mass [28, 41].

- Durometry is a method of assessing the activity of LoSc based on measurements of skin thickness on a 0 to 100 point scale [42]. The durometer is placed in a position perpendicular to the surface of the skin. The thickness of the skin is measured on the edges and in the centre of a lesion. In addition, a homolateral area of unaffected skin is measured as a control [42]. Seyger et al. have found a weak correlation between durometry results and MSS (modified skin score) [43].

- LS Cutaneous Assessment Tool (LoSCAT) is an assessment questionnaire for patients with LoSc introduced by the Localized Scleroderma Clinical and Ultrasound Study Group. It consists of modified LS Skin Severity Index (mLoSSI) and LS Skin Damage Index (LoSDI) which, according to the recommendations, should be used in combination with general medical evaluation (Physician's Global Assessment - PGA, Physician's Global Assessment of Disease Activity, Physician's Global Assessment of Damage) (Table 5) [44]. On account of its repeatability and consistency of assessment, as well as ease of use, the questionnaire seems to be a promising tool for evaluating patients with LoSc. mLoSSI is based on markers of severity/ activity of the disease including erythema, skin induration, and appearance of new/expansion narażenie na promieniowanie oraz konieczność stosowania znieczulenia u pacjentów pediatrycznych [29].

- Elektromiografia (electromyography - EMG) obiecująca metoda, która umożliwia diagnostykę czynności elektrycznej mięśni i nerwów obwodowych w przebiegu twardziny linijnej. Pierwsze badania z zastosowaniem EMG do oceny zajęcia tkanki mięśniowej przeprowadzili Magalhaes i wsp. u 9 pacjentów pediatrycznych z twardziną linijną (2 z PRS, 7 z twardziną linijną kończyn) [40]. Autorzy postulowali, że anomalie w układzie mięśniowym mogą być związane z wtórnym zajęciem obwodowego układu nerwowego [40].

- Computerized skin score (CSS) - metoda opisana po raz pierwszy w 2007 r. przez Zuliana i wsp. [28]. Polega na przyklejeniu do zmienionej chorobowo skóry przezroczystego opatrunku Tegaderm, a następnie zaznaczeniu markerem obszaru stwardnienia i strefy rumienia lilac ring, po wcześniejszej palpacji zmian [41]. W kolejnym etapie Tegaderm jest przenoszony na kartkę papieru, która po wprowadzeniu do specjalnego skanera polega digitalizacji [28]. Taka forma obrazu jest analizowana przez system komputerowy, który ocenia stosunek komponentu zapalnego do komponentu stwardnienia w obrębie zmian chorobowych [41]. Oprogramowanie pozwala także na precyzyjne obliczenie powierzchni ciała zajętej przez wykwity twardzinowe (body surface area - BSA) po wprowadzeniu do systemu wzrostu i masy ciała chorego $[28,41]$.

- Durometria - metoda oceny aktywności LoSc, która polega na pomiarze grubości skóry w skali od 0 do 100 pkt [42]. Durometr umieszcza się w pozycji prostopadłej do powierzchni skóry i mierzy się jej grubość na brzegach i w centrum wykwitu chorobowego, a także w obszarze skóry prawidłowej w jednoimiennej lokalizacji [42]. Seyger i wsp. stwierdzili słabą korelację pomiędzy wynikiem durometrii a MSS (modified skin score) [43].

- LS Cutaneous Assessment Tool (LoSCAT) - arkusz oceny pacjentów z LoSc wprowadzony przez Kliniczną i Ultrasonograficzną Grupę Badawczą Twardziny Ograniczonej. Składa się ze zmodyfikowanego wskaźnika aktywności lub nasilenia choroby (modified LS Skin Severity Index - mLoSSI) i uszkodzenia tkanek (LS Skin Damage Index - LoSDI), które wg rekomendacji powinny być stosowane w połączeniu z ogólną oceną lekarską (Physician's Global Assessment - PGA, Physician's Global Assessment of Disease Activity, Physician's Global Assessment of Damage) (tab. 5) [44]. Arkusz wydaje się obiecującym narzędziem ewaluacji pacjentów z LoSc, cechuje się powtarzalnością i zgodnością ocen, a także jest łatwy w użyciu. Arkusz mLoSSI uwzględnia wykładniki nasilenia lub aktywności procesu chorobowego, takie jak rumień, stwardnie- 


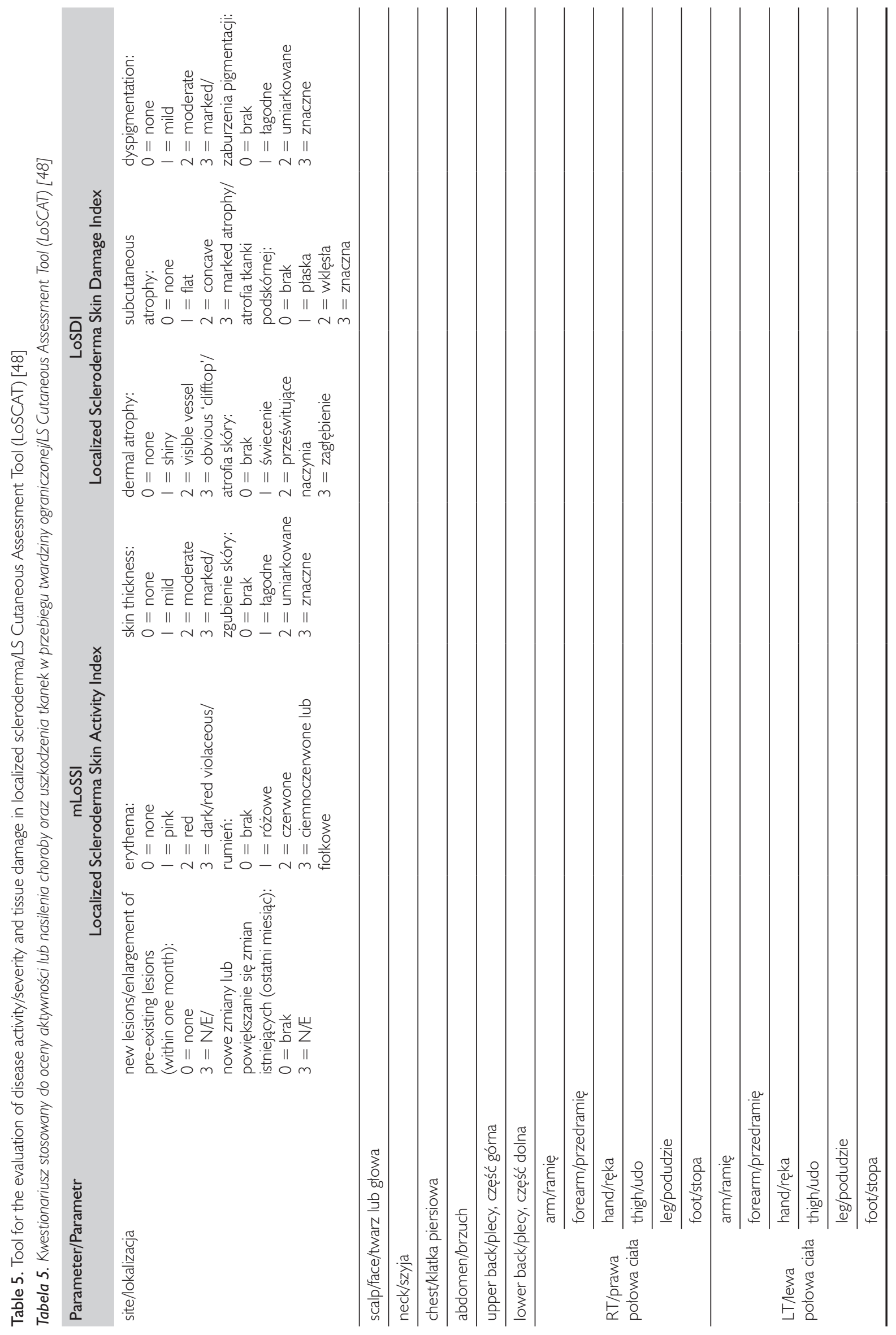


of pre-existing skin lesions during the preceding month [45]. Each of the three parameters is graded on a scale from 0 to 3 in 18 cutaneous anatomic sites (head/face, neck, chest, abdomen, upper back (from the $\mathrm{C} 7$ spinous process to the border of the last rib), lower back (from the border of the last rib to the intergluteal cleft), right and left arms, forearms, hands, thighs, legs and feet). The degree of erythema should be scored at the edge of a lesion: 0 - normal or postinflammatory hypo-/hyperpigmentation, 1 - slight erythema/pink, 2 - red/clearly erythema, and 3 - violaceous/marked erythema. Skin induration is estimated on the basis of palpation of the peripheral section of the lesions and the ability to pinch the skin into a fold: 0 - skin unaffected/easy to move; 1 - mild increase in thickness/ skin normal to move; 2 - moderate increase in thickness, skin difficult to move/pinch into a fold; 3 - severe thickness/impossible to pinch skin into a fold. (Skin thickness at the margin is considered to be secondary to inflammatory process and indicate active disease stage; in contrast, skin thickness at the centre of a lesion is a consequence of excessive collagen deposition and reflects tissue damage) [44]. Emergence of new lesions or enlargement of pre-existing lesions within the past month is scored 3 , and if the features are absent, a 0 score is given. The Childhood Arthritis and Rheumatology Research Alliance (CARRA) has distinguished two levels of parameters for the assessment of scleroderma activity in paediatric patients. Level 1 in- nie skóry, pojawianie się nowych wykwitów skórnych lub powiększenie już istniejących zmian w ciągu ostatniego miesiąca [45]. Każdy z trzech parametrów jest oceniany w skali od 0 do 3 pkt w obrębie 18 obszarów anatomicznych ciała (twarz lub głowa, szyja, klatka piersiowa, brzuch, górna część pleców - od wyrostka kolczystego C7 do brzegu ostatniego żebra, dolna część pleców - od brzegu ostatniego żebra do szpary międzypośladkowej, prawe kończyny - ramię, przedramię, ręka, udo, podudzie, stopa, lewe kończyny - ramię, przedramię, ręka, udo, podudzie, stopa). Nasilenie rumienia powinno być oceniane w obrębie brzegu zmiany: 0 - brak lub pozapalna hipo- lub hiperpigmentacja, 1 - delikatny rumień lub barwa różowa, 2 - nasilony rumień lub barwa czerwona, 3 - znaczny rumień lub zasinienie. Stwardnienie skóry szacuje się na podstawie palpacji części obwodowej zmian i próby ujęcia skóry w fałd: 0 skóra niezmieniona lub łatwo przesuwalna, 1 - niewielkie stwardnienie lub skóra przesuwalna, 2 - umiarkowane stwardnienie lub utrudniona przesuwalność skóry, lub trudności z ujęciem skóry w fałd, 3 - znaczne stwardnienie lub brak możliwości ujęcia skóry w fałd (stwardnienie brzegu zmiany jest wynikiem stanu zapalnego i świadczy o aktywności choroby $\mathrm{w}$ przeciwieństwie do stwardnienia $\mathrm{w}$ obrębie części centralnej, które jest spowodowane nadmiernym gromadzeniem kolagenu i odzwierciedla uszkodzenie tkanek) [44]. Pojawienie się nowych zmian lub powiększenie istniejących wykwitów w ciągu ostatniego miesiąca ocenia się na 3 pkt, a brak powyższych cech - 0 pkt. Grupa Childhood Arthritis and Rheumatology Research Alliance (CARRA) stworzyła

Table 6. Definition of LoSc activity in children based on The Childhood Arthritis and Rheumatology Research Alliance (CARRA) [50]

Tabela 6. Definicja aktywności LoSc u dzieci wg The Childhood Arthritis and Rheumatology Research Alliance (CARRA) [50]

\begin{tabular}{|c|c|}
\hline Level I/Kategoria I & Level 2/Kategoria 2 \\
\hline $\begin{array}{l}\text { appearance of new lesions (documented by the physician)/ } \\
\text { pojawienie się nowych zmian (udokumentowane przez lekarza) }\end{array}$ & $\begin{array}{l}\text { appearance of new lesions (according to the patient/patient's } \\
\text { parents - applicable only to new patients)/pojawienie się nowych } \\
\text { zmian (wg pacjenta lub rodziców pacjenta - podpunkt odnosi się } \\
\text { tylko do nowych pacjentów) }\end{array}$ \\
\hline $\begin{array}{l}\text { expansion of pre-existing lesions in the last } 3 \text { months } \\
\text { (documented by the physician)/powiększenie się istniejących } \\
\text { zmian w ciągu ostatnich } 3 \text { miesięcy (udokumentowane przez } \\
\text { lekarza) }\end{array}$ & lesion warmth/ucieplenie zmian \\
\hline moderate or severe erythema/umiarkowany lub nasilony rumień & mild erythema/delikatny rumień \\
\hline violaceous lesion colour/fiołkowe zabarwienie zmiany & $\begin{array}{l}\text { moderate/marked induration of lesion borders/umiarkowane lub } \\
\text { znaczne zgrubienie brzegów zmian }\end{array}$ \\
\hline \multirow{3}{*}{$\begin{array}{l}\text { documentation of disease progression to subcutaneous } \\
\text { tissue (by clinical examination, photography, MRI or USG)/ } \\
\text { udokumentowane zajęcie tkanki podskórnej (na podstawie } \\
\text { badania klinicznego, fotografii, MRI, USG) }\end{array}$} & $\begin{array}{l}\text { worsening of hair loss on the scalp, eyebrows or eyelashes } \\
\text { (documented by the physician)/nasilenie utraty włosów, brwi, } \\
\text { rzęs (udokumentowane przez lekarza) }\end{array}$ \\
\hline & $\begin{array}{l}\text { increased creatine kinase (following exclusion of other possible } \\
\text { causes)/podwyższenie stężenia kinazy kreatyninowej (przy } \\
\text { wykluczeniu innych możliwych przyczyn) }\end{array}$ \\
\hline & $\begin{array}{l}\text { skin biopsy demonstrating active disease/wynik biopsji wskazujący } \\
\text { na aktywny proces chorobowy }\end{array}$ \\
\hline
\end{tabular}


Table 7. Clinical variables determining physician's global assessment of disease activity (PGA-A) [5I]

Tabela 7. Cechy kliniczne determinujq̨ce ogólnq ocenę lekarskq̨ dotyczq̨cq aktywności choroby (PGA-A) [5 I]

\begin{tabular}{ll}
\hline Very/extremely important/ & - new lesions within the previous month/pojawienie się nowych ognisk w ciągu ostatniego miesiąca \\
Bardzo duża lub duża & - enlargement of existing lesions within the previous month/powiększenie się istniejących zmian \\
istotnośc & w ciągu ostatniego miesiąca \\
& - erythema/violaceous colour of lesion borders/rumień lub zasinienie brzegu zmiany \\
& - uveitis/zapalenie naczyniówki \\
\hline Moderately important/ & - skin induration at the border of lesion/zgrubienie brzegu zmiany \\
Umiarkowana istotność & \\
\hline Mildly important/ & - dermal atrophy/zanik skóry \\
unimportant/ & - subcutaneous tissue atrophy/zanik tkanki podskórnej \\
Mała istotność lub brak & - physical disability/niepełnosprawność fizyczna \\
istotności & - dyspigmentation (hypo-/hyperpigmentation)/dyspigmentacja (hipo- lub hiperpigmentacja) \\
& - facial atrophy/atrofia mięśni twarzy \\
& - skeletal muscle atrophy/atrofia mięśni szkieletowych \\
& - quality of life impairment/negatywny wpływ na jakość życia \\
& - joint contracture/przykurcze w stawach \\
& - cataract/glaucoma/zaćma lub jaskra
\end{tabular}

Table 8. Clinical variables determining physician's global assessment of the extent of damage (PGA-D) [48]

Tabela 8. Cechy kliniczne determinujq̨ce ogólnq ocenę lekarskq̨ dotyczq̨cq rozległości uszkodzeń zwiq̨zanych z chorobą (PGA-D) [48]

\begin{tabular}{ll}
\hline Very important/Bardzo istotne & - facial atrophy/zanik mięśni twarzy \\
& - skeletal muscle atrophy/zanik mięśni szkieletowych \\
& - physical disability/niepełnosprawność fizyczna \\
& - joint contracture/przykurcze w stawach \\
& - bone atrophy/atrofia kości \\
& - cataract/glaucoma/zaćma lub jaskra \\
& - limb length discrepancy/rozbieżna długość kończyn \\
& - subcutaneous tissue atrophy/atrofia tkanki podskórnej \\
& - CNS symptoms, e.g. seizures/objawy neurologiczne, np. drgawki \\
& - dyspigmentation/dyspigmentacja \\
& - quality of life impairment/negatywny wpływ na jakość życia \\
\hline Moderately important/Umiarkowanie istotne & - dermal atrophy/atrofia skóry \\
\hline
\end{tabular}

cludes features for which expert consensus has been reached regarding their significance, and level 2 comprises parameters for which partial expert consensus has been achieved (Table 6) [46]. For a patient to be considered to have active disease, a single level 1 parameter or two level 2 parameters had to be identified [46]. Subjective physician assessment of disease activity (PGA-A) should be based on clinical variables classified into three groups depending on the consensus agreement (Table 7) [47]. Tissue damage secondary to LoSc is assessed on the basis of dermal atrophy (0 - none, 1 - mild atrophy/ shiny skin, 2 - moderate atrophy/visible vessels, 3 - marked atrophy/'cliffdrop') and subcutaneous atrophy $(0-$ none, $1-$ flat, $\leq 1 / 3$ fat loss, 2 - concave, 1/3-2/3 fat loss, 3 - marked atrophy, $\geq 2 / 3$ fat loss), and hypo-/hyperpigmentation $(0$ - none, 1 - mild, 2 - moderate, 3 - marked). Clinical factors considered in subjective physician assessment of the extent of tissue damage (PGA-D) are divided into very important and moderately important (Table 8) [44]. Every score is calculated on the basis dwie kategorie parametrów pozwalających na ocenę aktywności twardziny u pacjentów pediatrycznych. Kategoria 1 zawiera cechy, które otrzymały zgodne oceny ekspertów w zakresie istotności, a kategoria 2 cechy, co do których eksperci nie są w pełni zgodni (tab. 6) [46]. Stwierdzenie aktywnego procesu chorobowego opierało się na wykazaniu obecności jednego parametru z kategorii 1 bądź dwóch parametrów z kategorii 2 [46]. Subiektywna ocena lekarska aktywności choroby (PGA-A) powinna bazować na cechach klinicznych, które zostały zakwalifikowane do trzech grup, w zależności od zgodności ocen (tab. 7) [47]. Uszkodzenie tkanek w przebiegu LoSc określa się na podstawie oceny atrofii skóry $(0$ - brak, 1 - niewielka atrofia lub skóra błyszcząca, 2 - umiarkowana atrofia lub prześwitujące naczynia, 3 - znaczna atrofia lub zagłębienie) i tkanki podskórnej ( 0 - brak, 1 - płytkie wgłębienie, utrata $\leq 1 / 3$ tkanki tłuszczowej, 2 - wklęśnięcie, utrata 1/3-2/3 tkanki tłuszczowej, 3 - znaczna atrofia, utrata $\geq 2 / 3$ tkanki tłuszczowej) oraz hipo- lub hiperpigmetacji ( 0 - brak, 1 - niewielka, 2 - umiarkowana, 3 - znaczna). Czynniki kliniczne uwzględniane w subiektywnej ocenie lekarskiej stopnia uszkodzenia tkanek (PGA-D) po- 
of the most severe lesion identified within a given body region. The maximum score for each index (mLoSSI and LoSD) is 162. No interpretation has as yet been proposed for the above indices depending on the awarded score. PGA-A and PGA-D are assessed on a scale from 0 (inactive disease/no tissue damage) to 100 (high disease activity/severe tissue damage). According to Kelsey et al. subjective physician assessment of disease activity correlates with patient response to systemic therapy [48].

\section{SUMMARY}

Localized scleroderma (morphea) is a disease of autoimmune origin which may run a different course depending on its clinical form. According to the most recent classification, five main clinical types of LoSc are distinguished: localized, generalized, linear, deep and mixed. The course of LoSc remains difficult to predict. Various methods have been proposed for the evaluation of disease activity/severity and tissue damage, including ultrasonography, thermography, durometry, CT and MRI. The methods, however, have their limitations, as they only make it possible to assess one component of the disease: activity/severity or tissue damage [49]. The LoSCAT questionnaire is a promising method of patient evaluation because of its availability, repeatability of results and sensitivity to changes resulting from treatment. LoSCAT allows a fast and easy assessment of both parameters: disease severity/activity and tissue damage. A disadvantage of the method is the fact that it excludes extracutaneous manifestations of the disease such as musculo-articular lesions, neurological complications and eye involvement, which reflect tissue damage secondary to LoSc [49]. It seems appropriate to use the LoSCAT form along with other assessment methods adequate for a given clinical form of LoSC. A combination of various forms of evaluation makes it possible to analyze the severity/activity of the disease and tissue damage, and assess the efficacy of therapy.

\section{CONFLICT OF INTEREST}

The authors declare no conflict of interest. dzielono na bardzo istotne i umiarkowanie istotne (tab. 8) [44]. Każdy wynik szacuje się na podstawie najbardziej nasilonej zmiany w obrębie danej okolicy ciała. Maksymalna wartość każdego ze wskaźników (mLoSSI i LoSD) wynosi 162 pkt. Dotychczas nie zaproponowano interpretacji powyższych wskaźników w zależności od przyznanej punktacji. PGA-A i PGA-D ocenia się w skali od 0 (choroba nieaktywna lub brak uszkodzenia tkanek) do 100 (choroba o dużej aktywności lub duże uszkodzenie tkanek). Według Kelsey i wsp. subiektywna ocena lekarska aktywności choroby koreluje z odpowiedzią na leczenie systemowe [48].

\section{PODSUMOWANIE}

Twardzina ograniczona jest chorobą o podłożu autoimmunologicznym, która może mieć różny przebieg w zależności od postaci klinicznej. Zgodnie z najnowszym podziałem wyróżnia się pięć głównych typów klinicznych LoSc - twardzinę ograniczoną plackowatą, uogólnioną, linijną, głęboką i mieszaną. Przebieg LoSc jest trudny do przewidzenia. Zaproponowano wiele metod oceny nasilenia lub aktywności choroby oraz uszkodzenia tkanek, takich jak ultrasonografia, termografia, durometria, CT czy MRI. Ograniczenia powyższych badań wynikają z możliwości oceny tylko jednego wykładnika choroby - nasilenia lub aktywności albo uszkodzenia tkanek [49]. Metoda oparta na zastosowaniu kwestionariusza LoSCAT jest godna uwagi ze względu na dostępność narzędzi, powtarzalność wyników, a także czułość na zmiany wynikające z zastosowanego leczenia. Formularz LoSCAT pozwala w łatwy i szybki sposób ocenić oba parametry - nasilenie lub aktywność choroby oraz uszkodzenie tkanek. Jej wadą jest nieuwzględnienie manifestacji pozaskórnych, takich jak zmiany mięśniowo-stawowe, powikłania neurologiczne, zajęcie narządu wzroku, które odzwierciedlają uszkodzenie tkanek w przebiegu LoSc [49]. Słuszne wydaje się stosowanie formularza LoSCAT wraz z innymi metodami oceny, odpowiednio do postaci klinicznej LoSc. Połączenie różnych form ewaluacji pozwala na analizę nasilenia lub aktywności choroby oraz uszkodzenia tkanek, a także ocenę skuteczności zastosowanego leczenia.

\section{KONFLIKT INTERESÓW}

Autorki deklarują brak konfliktu interesów. 


\section{References}

\section{Piśmiennictwo}

1. Careta M.F.: Localized scleroderma: clinical spectrum and therapeutic update. An Bras Dermatol 2015, 90, 62-73.

2. Kreuter A., Krieg T., Worm M., Wenzel J., Moinzadeh P.: German guidelines for the diagnosis and therapy of localized scleroderma. J Dtsch Dermatol Ges 2016, 14, 199-216.

3. Marsol B.: Update on the classification and treatment of localized scleroderma. Actas Dermosifiliogr 2013, 104, 654-666.

4. Wojas-Pelc A., Wielowieyska-Szybińska D.: Obraz kliniczny twardziny skórnej. Przegl Lek 2007, 64, 438-441.

5. Garcia-Romero M.T., Laxer R., Pope E.: Correlation of clinical tools to determine activity of localized scleroderma in paediatric patients. Br J Dermatol 2016, 174, 408-410.

6. Kreuter A.: Localized scleroderma. Dermatol Ther 2012, 25, 135-147.

7. Mertens J.S., Seyger M.M.B., Kievit W., Hoppenreijs E.P.A.H., Jansen T.L.T.A., van de Kerkhof P.C., et al.: Disease recurrence in localized scleroderma: a rerospective analysis of 344 patients with paediatric- or adult-onset disease. Br J Dermatol 2015, 172, 722-728.

8. Peterson L.S., Nelson A.M., Su W.P.D.: Classification of morphea (localized scleroderma). Mayo Clin Proc 1995, 70, 19681976.

9. Fett N., Wrth V.: Update on morphea. J Am Acad Dermatol 2010, 64, 217-227.

10. Krieg T.: Twardzina. [In:] Dermatologia Braun Falco. W. Gliński (ed.), Czelej, Lublin, 2011, 725-740.

11. Laxer R., Zulian F.: Localized scleroderma. Curr Opin Rheumatol 2006, 18, 606-613.

12. Kreuter A., Krieg T., Worm M., Wenzel J., Gambichler T., Kuhn A., et al.: Diagnosis and therapy of localized scleroderma. J Ger Soc Dermatol 2009, 7, 1-12.

13. Torok K.S.: Pediatric scleroderma - systemic and localized forms. Pediatr Clin North Am 2012, 59, 381-405.

14. Hanami Y., Ohtsuka M., Yamamoto T.: Paraneoplastic eosinophilic fascitis with generalized morphea and vitiligo in a patient working with organic solvents. J Dermatol 2016, 43, 67-68.

15. Hiraiwa T., Mori T., Ohashi T., Hanami Y., Yamamoto T.: Eosinophilic fascitis with severe joint contracture in a patient with bladder cancer and B-cell lymphoma. J Dermatol 2016, 43, 68-69.

16. Dharamsi J.W., Victor S., Aguwa N., Ahn C., Arnett F.: Morphea in adults and children cohort III. JAMA Dermatol 2013, 149, 1159-1165

17. Wu E., Rabinovich E.C., Torok K.S., Li S.C., Fuhlbrigge R., CARRAnet Investigators: Description of the localized scleroderma subgroup of CARRAnet. Pediatr Rheumatol 2012, 10, 1-2.

18. Zulian F., Athreya B.H., Laxer R., Nelson A.M., Feitosa de Oliveira S.K.: Juvenile localized scleroderma: clinical and epiemiological features in 750 children. An international study. Rheumatology 2006, 45, 614-620.

19. Mazori D.R., Wright N.A., Patel M., Liu S.W., Ramachandran S.M.: Characteristics and treatment of adult-onset linear morphea: a retrospective cohort study of 61 patients at 3 tertiary care center. J Am Acad Dermatol 2016, 74, 577-579.

20. Garza F.Z.M., Mercade E.M., Crespo E.R., Sanz L.P., Torres E.B.: Linear morphea mimicking lichen stratus in its early presentation. Pediatr Dermatol 2016, 33, 23-26.

21. Careta M.F., Leite C.C., Cresta F., Albino J., Tsunami M.: Prospective study to evaluate the clinical and radiological outcome of patients with scleroderma of the face. Autoimmunity Rev 2013, 12, 1064-1069.

22. Amaral T.N., Neto J.F.M., Lapa A.T., Peres F.A., Guirau C.R.: Neurologic involvement in scleroderma en coup de sabre. Autoimm Dis 2012, 2012, 719685.

23. Lis-Święty A., Milewska-Wróbel D., Zielonka-Kucharzewska A., Brzezińska-Wcisło L.: Morphea on the face and head: a different clinical picture and disease course in three cases. Int J Dermatol 2015, 54, 149-153.

24. Khan M., Khan M., Negi R., Gupta N.: Parry-Romberg syndrome with localized scleroderma: a case report. J Clin Exp Dent 2014, 6, e313-e316.

25. Maletic J., Tsirka V., Ioannides P., Karacostas D., Taskos N.: Parry-Romberg syndrome associated with localized scleroderma. Case Rep Neurol 2010, 2, 57-62.

26. Nomura H., Egami S., Yokoyama T., Sugiura M.: Case of rapid progression of hemiatrophy on the face: a new clinical entity. Case Rep Dermatol Med 2015, 2015, 478640.

27. Bergler-Czop B., Brzezińska-Wcisło L., Meszyńska E.: Twardzina ograniczona pęcherzowa - opis przypadku. Przegl Dermatol 2010, 97, 390-394.

28. Zulian F., Meneghesso D., Grisan E., Vittadello F., Fortina A.B., Pigozzi B., et al.: A new computerized metod for the assessment of skin lesions in localized scleroderma. Rheumatology 2007, 46, 856-860.

29. Li S.C., Liebling M.S., Haines K.A.: Ultrasonography is a sensitive tool for monitoring localized scleroderma. Rheumatology 2007, 46, 1316-1319.

30. Bendeck S.E., Jacobe H.T.: Ultrasound as an outcome measure to assess disease activity in disorders of skin thickening: an example of the use of radiologic techniques to assess skin disease. Dermatol Ther 2007, 20, 86-92.

31. Liebling S.C.M.S., Haines K.A., Weiss J.E., Prann A.: Initial evaluation of an ultrasound measure for assessing the activity of the skin lesions in juvenile localized scleroderma. Arthritis Care Research 2011, 63, 735-742.

32. Wortsman X., Wortsman J., Szunic I., Carrero L.: Activity assessment in morphea using color Doppler ultrasound. J Am Acad Dermatol 2011, 65, 942-948.

33. Weibel L., Howell K.J., Visentin M.T., Rudiger A., Denton C.P.: Laser Doppler flowmetry for assesing localized scleroderma in children. Arthritis Rheum 2007, 56, 3489-3495.

34. Shaw L.J., Shipley J., Newell E.L., Harris N., Clinch J.G.: Scanning laser Doppler imaging may predict disease progression of localized scleroderma in children and young adults. Br J Dermatol 2013, 169, 152-155.

35. Murray A., Moore T.L., Manning J.B., Dinsdale J.B., Wilkinson J.: Non-invasive imaging of localized scleroderma for assessment of skin blood flow and structure. Acta Derm Venereol 2016, 96, 641-644.

36. Martini G., Murray K.J., Howell K.J., Harper J., Atherton D.: Juvenile-onset localized scleroderma activity detection by infrared thermography. Rheumatology 2002, 41, 1178-1182. 
37. Howell K.J., Lavorato A., Visentin M.T., Smith R.E., Shaefer G.: Validation of a protocol for the assessment of skin temperature and blood flow in childchood localized scleroderma. Skin Res Technol 2009, 15, 346-356.

38. Horger M., Fierlbeck G., Kuemmerle-Deschner J., Tzaribachev N., Wehrmann M.: MRI findings in deep and generalized morphea (localized scleroderma). Am J Roentgenol 2009, 190, 32-34.

39. Khan M.A., Shaw L., Eleftheriou D., Prabhakar P., Chong W.K., Glover M.: Radiologic improvement after early medical intervention in localized facial morphea. Pediatr Dermatol 2016, 33, 1-4.

40. Magalhaes C.S., Fernandes T.A.P., Fernandes T.D., Resende L.A.L.: A cross-sectional electromyography assessment in linear scleroderma patients. Pediatr Rheumatol 2014, 12, 27-31.

41. Fett N., Wrth V.P.: Update on morphea. Part II. Outcome measures and treatment. J Am Acad Dermatol 2011, 64, $231-242$.

42. Poff S., Li S.C., Kelsey C.E., Foeldvari I., Torok K.S.: Durometry as an outcome measure in juvenile localized scleroderma. Br J Dermatol 2016, 174, 228-230.

43. Seyger M.M., Van den Hoogen F.H., De Boo T., De Jong E.M.: Reliability of two methods to assess morphea: skin scoring and the use of a durometer. J Am Acad Dermatol 1997, 37, 793-796.

44. Arkachaisri T., Vilaiyuk S., Torok K.S., Medsger T.A.: Development and initial validation of the localized scleroderma skin damage index and physical global assessement of disease damage: a proof of concept study. Rheumatology 2010, 49, 373-381.

45. Arkachaisri T., Pino S.: Localized scleroderma severity index and global assessments: a pilot study of outcome instruments. J Rheumatol 2008, 35, 650-657.

46. Li S.C., Torok K.S., Pope E., Dedeoglu F., Hong S., Jacobe H.T., et al.: Development of consensus treatment plans for juvenile localized scleroderma. Arthritis Care Res 2012, 64, 1175-1185.

47. Arkachaisri T., Vilaiyuk S., Li S., O'Neil K.M., Pope E.: The localized scleroderma skin severity index and physician global assessment of disease activity: a work in progress toward development of localized scleroderma outcome measures. J Rheumatol 2009, 36, 2819-2829.

48. Kelsey C., Torok K.: The localized scleroderma assessment tool (LoSCAT) responsiveness to change in a pediatric clinical population. J Am Acad Dermatol 2013, 69, 214-220.

49. Lis-Święty A., Janicka I., Skrzypek-Salamon A., Brzezińska-Wcisło L.: A systematic review of tools for determining activity of localized scleroderma in paediatric and adult patients. J Eur Acad Dermatol Venereol 2017, 1, 30-37.

Received: 29.01.2017

Accepted: 5.04.2017

Otrzymano: 29.01.2017 r

Zaakceptowano: $5.04 .2017 \mathrm{r}$ 